\title{
Understanding the Performance of Vertical Gardens by Using Building Simulation and its Influences on Urban Landscape
}

\author{
Faezeh Bagheri Moghaddam ${ }^{1}$ | Isidro Navarro Delgado ${ }^{2}$ | Ernest Redondo Dominguez ${ }^{3}$ | Josep Maria \\ Fort Mir ${ }^{4}$ I Lluís Giménez Mateu ${ }^{5}$
}

Received: 2021-01-21 | Final version: 2021-05-25

\begin{abstract}
Urban development can have a profound impact on the health and well-being of people, sustainability of cities, increasing energy consumption because of increasing urban heat island (UHI), and $\mathrm{CO}_{2}$ which is one of the environmental and social concerns. The vertical garden as a second skin on the façade has been analyzed in this paper, are compared using several constructive alternatives in a natural and sustainable way. The main proposal of this study is a second skin (green façade) in an office building in Barcelona, Spain, that is in southwest orientation, which aims to reduce energy consumption as much as possible and improve the urban landscape, and pedestrian comfort. Vertical gardens as a second skin are implemented on the building's exterior walls to intercept a quantity of solar radiation towards the vertical building envelope. The methodology is based on the evaluation of various green facade options through simulation of the different sizes of the cavity's depth with a specific orientation. According to the result of the simulation obtained from Autodesk Green Building Studio, the cavity's depth, and the density of plants (R-Value) are very effective in the performance of the green facade which must be calculated as specified by the building main facade's materia and structure, building orientation, the height of the building, and climate. This paper presents a case study that applies this approach in an office building located in Passeig de Gràcia, L'Eixample area in Barcelona.
\end{abstract}

Keywords: Green façade; building simulation; energy consumption; urban landscape

Citation

Bagheri, F. et al. (2021). Understanding the Performance of Vertical Gardens by Using Building Simulation and its Influences on Urban Landscape. ACE Architecture, City and Environment, 16(47), 10321. DOI: http://dx.doi.org/10.5821/ace.16.47.10321

\section{Comprender el rendimiento de los jardines verticales mediante el uso de la simulación de edificios y sus influencias en el paisaje urbano}

Resumen El desarrollo urbano puede tener un impacto profundo en la salud y el bienestar de las personas, la sostenibilidad de las ciudades, el aumento del consumo de energía debido al aumento de la "isla de calor urbano' (UHI) y también el $\mathrm{CO}_{2}$, que es una de las preocupaciones ambientales y sociales. En este trabajo ha sido analizado el jardín vertical como segunda piel en la fachada, se comparan utilizando varias alternativas constructivas de forma natural y sostenible. La propuesta principal de este estudio es una segunda piel (fachada verde) en un edificio de oficinas en Barcelona (España) que se encuentra en orientación suroeste, que tiene como objetivo reducir al máximo el consumo energético y también mejorar el paisaje urbano. Los jardines verticales, como segunda piel, se implementan en los muros exteriores del edificio para interceptar una cantidad de radiación solar hacia la envolvente vertical del edificio. La metodología se basa en la evaluación de varias opciones de fachadas verdes mediante la simulación de los diferentes tamaños de la profundidad, orientación y altura de la cavidad del edificio. De acuerdo con el resultado de la simulación obtenido de Autodesk Green Building Studio, la profundidad de la cavidad de la fachada verde como segunda piel es muy efectiva. La profundidad de cavidad debe calcularse según lo especificado por el material de la fachada principal del edificio y estructura, orientación del edificio, altura del edificio y clima. Este artículo presenta un caso de estudio que aplica este enfoque en un edificio de oficinas ubicado en Passeig de Gràcia, zona del Eixample en Barcelona.

Palabras clave: Fachada verde; edificio de oficinas; consumo de energía; paisaje urbano

1 Ph.D. candidate in Architectural, Civil, Urban Heritage and Rehabilitation of Existing Constructions, Architecture School of Barcelona, ETSAB-UPC, Universitat Politècnica de Catalunya, Spain (ORCiD: 0000-0002-1809-0855), ${ }^{2}$ Lecturer, Architecture School of Barcelona, ETSAB-UPC, Spain (ORCID: 0000-0002-5511-4043), ${ }^{3}$ Head of the research group, Associate Professor, Architecture School of Barcelona, ETSAB-UPC, Spain (ORCiD: 0000-0002-6633-4471), ${ }^{4}$ Adjunct Professor, Architecture School of Barcelona, ETSAB-UPC, Spain (ORCiD: 0000-0003-2846-3050), ${ }^{5}$ Head of Department, Adjunct Professor, Architecture School of Barcelona, ETSAB-UPC, Spain (ORCiD: 0000-0002-4025-1977). Contact e-mail: faezeh.bagheri.moghaddam@upc.edu 


\section{Introduction}

We have to take responsibility for sustainability challenges which we are facing, and the European Union has issued (Hensen \& Lamberts, 2011; Skjærseth \& Wettestad, 2010) that rather than a strict 2020-20 initiative (relative to 1999), by 2020 20\% reduction of energy consumption, 20\% reduction of CO2, and 20\% introduction of renewable energy (Verbong \& Loorbach, 2012), but how much of this issue has been done in the year 2020? Merely for these reasons, more accurate guidelines have been boosted by many countries all over the world such as Denmark that the Danish Government has proposed a target of 30\% renewable energy for the year 2025 (Lund \& Mathiesen, 2009). For e.g., Lund and Mathiesen (2009) discussed that the initial step towards long-term goals must be under these initiatives and guidelines. To gain these sustainability targets requires the development of buildings in urban planning such as implementing greenery buildings. For this purpose, equipment and models for simulation would be needed to consider the urban-scale energy consumption. In this case, it can be achieved by global optimization of energy production and use in the built environment.

In the challenge of urban development, preserving sustainability and the environment in urban areas is a substantial issue that vertical garden (green facade) is one of those approaches that have thrived during the last decade. Applying vertical gardens in building envelopes in different climates can be used as a way to improve the environmental conditions in urban zones. Vertical gardens and all the greenery ways can be implemented for reducing the effect of urban heat island (UHI) and energy consumption, which nowadays is vital because of the global warming issue (Kolokotroni et al., 2012; Palme et al., 2017; Li et al., 2019; Hwang et al., 2017). Besides, growing biodiversity and ecological value, improving air quality for city dwellers, outdoor and indoor comfort, preserving against environmental impact, social and psychological well-being, and enhancing living conditions for building occupant (Rakhshandehroo et al., 2015).

Nowadays, reducing energy consumption is one of the significant concerns (Frenger et al., 2011; Bilgen, 2014). Summer in the Mediterranean and arid climate is more associated with this issue. Increasing energy consumption depends on many items and over the last few decades, the wide use of air conditioning in buildings has caused to raise energy consumption (Pérez-Lombard et al., 2008; Dall'o' et al., 2012; Rey et al., 2007). This issue is crucial because electricity usage is growing much more than Gross Domestic Product (GDP), primary energy consumption, and population increase (Plan Bleu (Regional Activity Center), 2015; Efficiency \& Summary, 2011). Moreover, urban warming and climate change contribute to growing the cooling energy consumption (Grimmond, 2007) even more in this context. A growth of tropical nights (>20 C) and also hot days (>35 C) for the Mediterranean basin are anticipated by climate scenarios for the next 100 years (Hans-Martin et al., 2012).

This paper simulated an office building (non-residential) as a case study because non-residential buildings consume on average 25\% energy of the total European building stock, demonstrating a heterogeneous part compared with the residential (European System of Accounts, 1995). With regards to a BPIE (Buildings Performance Institute Europe) survey (Toleikyte et al., 2016), non-residential buildings in Europe can be divided into the following categories: wholesale \& retail (28\%), offices (23\%), educational (17\%), hotels, and restaurants (11\%), hospitals (7\%), sports facilities (4\%), other (11\%). In the last decade, electricity consumption has grown on average by 74\% (D'Agostino, et al., 2017a). One of these reasons for growth is that in the non-residential buildings (e.g. offices, shops, schools, hospitals) electric consumption related to light, ventilation, heating, cooling, refrigeration, IT equipment and facilities modify significantly from one category to another (D'Agostino, et al., 2017b). Because of that non-residential buildings need on average 55\% more electrical energy than residential buildings (Economidou et al., 2011).

ACE, 16 (47) CC BY-ND 3.0 ES | UPC Barcelona, España | Understanding the Performance of Vertical Gardens by Using Building Simulation and its Influences on Urban Landscape. DOI: http://dx.doi.org/10.5821/ace.16.47.10321 
A significant increase in the buildings' energy consumption is because of high temperature, as a result, temperature directly affects the cooling demand (Akbari et al., 1997; Rosenfeld et al., 1995; Rosenfeld et al., 1997; De La Flor \& Domínguez, 2004; Hassid et al., 2000; Oxizidis et al., 2008; Sun \& Augenbroe, 2014). Actually, due to climate and urban heat island (UHI) scenarios, temperate and mid-latitude climates will face the most significant growth in annual energy consumption, because not only in summer, also in autumn and spring periods cooling will be needed (Invidiata \& Ghisi, 2016; Crawl, 2008).

This paper aims to introduce a way to reduce energy consumption by applying green façade as a second skin in a dense urban area facing the Mediterranean Sea and its impact on energy demand for office buildings by using Autodesk Green Building Studio (GBS) as a simulation software to prove the ability of this application to design high-performance buildings at a fraction of the time and cost of conventional methods (Luziani \& Paramita, 2019; Aljundi et al., 2016). Choosing the office building for simulation is because of the growth of electric consumption in office buildings as non-residential buildings, especially office buildings with glazing facades.

\section{Methodology}

In this paper, an initial case study has been introduced, carried out in the context of green building design in Passeig de Gràcia, L'Eixample area in Barcelona (Figure 1-2). The case study is conceptual with cubic shape and it is not a real building but with a specific location. It searches and discovers the simulation's potential performance when using vertical gardens to reduce energy consumption and especially electric use. This research is focused on an office building with the glazing façade as the main façade (single skin facade and green skin façade with five different specifications) which is located in southwest orientation, that can be used to determining the amount of energy consumption, cost, and Energy Use Intensity (EUI) ${ }^{1}$ of the office building to discover the ways of reducing energy consumption which could improve conditions for working as well as psychologically and aesthetically for pedestrians. The cause of choosing southwest orientation for this research is that according to our previous research, the green facade performance located in the southwest is significant by about $71.2 \%$ reduction of annual electrical use and reduced total annual energy cost by approximately 17.9\%, and decreased EUI about $36.8 \mathrm{MJ} / \mathrm{m}^{2} /$ year (Bagheri Moghaddam et al., 2020). These kinds of building simulations allow a profound analysis of the approach's capabilities to predict energy consumption (Bagheri Moghaddam et al., 2021; Yezioro et al., 2008). Building simulations as a first step is critical to developing 'predictive capabilities' (Øren et al., 1998; Zhao \& Magoulès, 2012) that building behavior can be used to identify potential changes for reducing energy consumption (De Wilde et al., 2013).

The first set is presenting the vertical garden in more detail. An initial list introduces energy demand reduction strategies that can help building to reduce energy use. The paper concentrates on the case study, introducing ways on perform a crucial role in building facades strategies developed from the long list of strategies to those involved that are supposed possible in this context. These strategies shortlist analyzed for propounding the optimal ways to use computation (energy use, cost, and EUI) to discover the most promising strategy.

${ }^{1}$ The EUI is demonstrated as energy per square foot per year. It's calculated by dividing the total energy consumed by the building in one year (measured in kBtu or GJ) by the total gross floor area of the building.

ACE, 16 (47) CC BY-ND 3.0 ES | UPC Barcelona, España | Understanding the Performance of Vertical Gardens by Using Building Simulation and its Influences on Urban Landscape. DOI: http://dx.doi.org/10.5821/ace.16.47.10321 


\section{ACE Architecture, City and Environment}

Figure 1. The exact location of the case study (Passeig de Gràcia, 20, Barcelona)

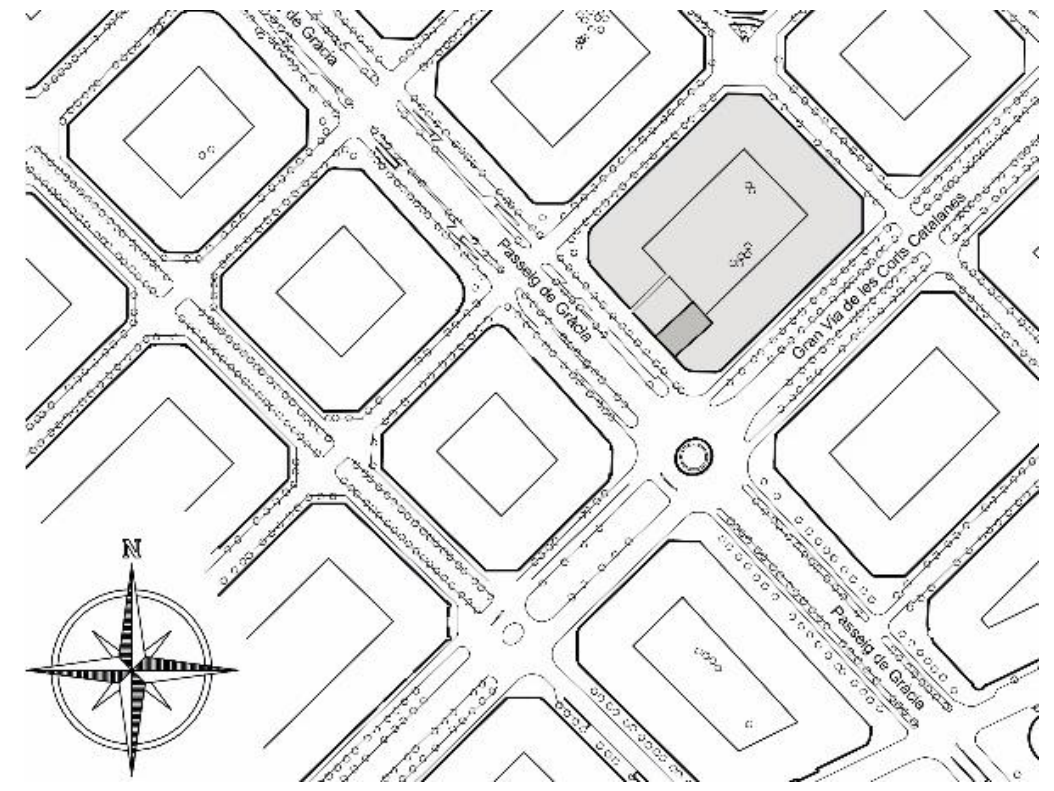

Source: By Author.

Figure 2. Barcelona architecture, high angle view of the city

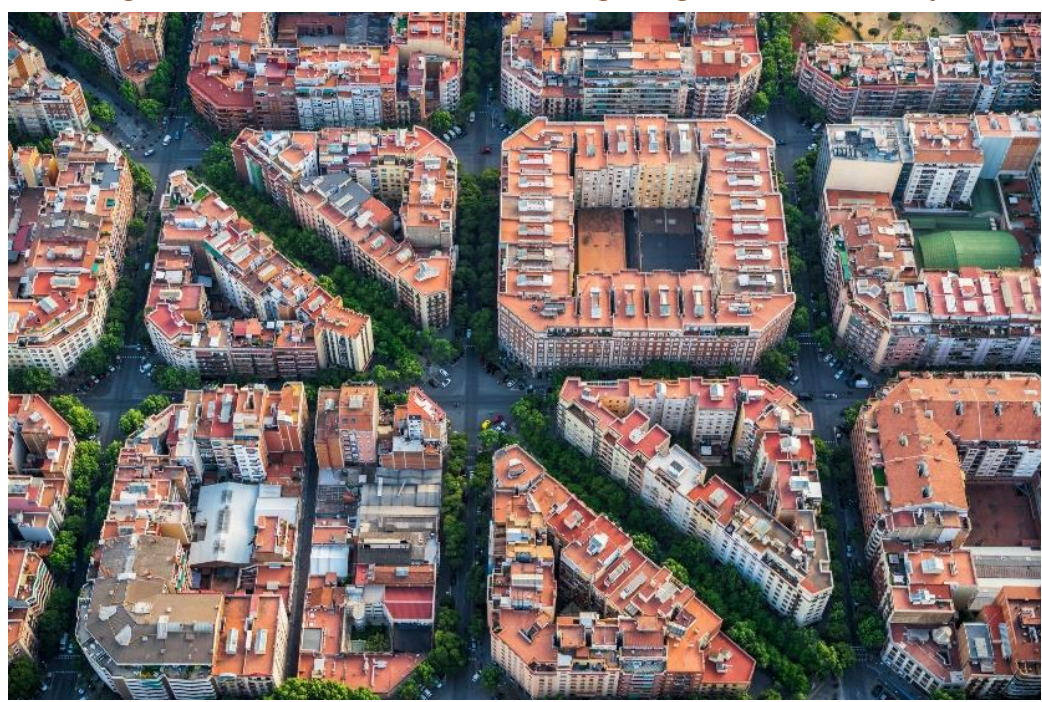

Source: Google.

Double skin facades are defined as two facade layers (building's facade is as a first layer which could be covered with stone/brick or glass, etc., the green facade is as a second layer which covered by plants and implemented on the first layer.) which are separated by an air space (cavity) (Poirazis, 2004). According to the separation method between the two facades, double-skin facades have been classified (Double-Skin Facades Integrated Planning, 2020) into boxed windows, shafts, and corridor or multi-story facades (GhaffarianHoseini et al., 2016). Green facades (vertical gardens) in different climates have been previously studied peak load reduction from a green facade as a second skin with a reflective double skin was predicted at $20 \%$ reduced energy consumption (Djedjig et al., 2015).

ACE, 16 (47) CC BY-ND 3.0 ES | UPC Barcelona, España | Understanding the Performance of Vertical Gardens by Using Building Simulation and its Influences on Urban Landscape. DOI: http://dx.doi.org/10.5821/ace.16.47.10321 
In this paper, we simulated different green façade types with varying size of depth cavity depth, different amount of surface that covered by plants, and the density of plants that can increase significantly the R-Value of the green façade (in this case, the density of plants is the same in all green façade types), and also glazing façade as the main façade in an office building that is located in one of the main and busiest streets in Barcelona, the width of this street is 40 meters with 10 meters sidewalk in each side.

For this purpose, a single skin façade (glazing facade), green skin façade (vertical garden) with 100\% and $50 \%$ amount of surface that is covered by the plants without depth cavity, and $10 \mathrm{~cm}$ and $50 \mathrm{~cm}$ depth cavity have been compared. The following configurations were set to calculate annually and monthly building energy consumption and the results were obtained using Autodesk Green Building Studio (GBS).

Revit and energy simulation have modeled the case study by GBS, which has powered the Revit energy analysis features. GBS uses the DOE2.2 dynamic thermal entire building energy simulation engine to estimate building energy use and operating costs; which are based on the effects and interactions of building form, materials, systems, usage, and climate. Furthermore, GBS has needed the minimum information for a simulation to generate an energy model by a default value. These default values are based upon the ASHRAE 90.1, ASHRAE 90.2, ASHRAE 62.1, and CBECS data, and also change with building type, size, number of floors, and location.

\subsection{Analyzing the context of Barcelona}

Barcelona (latitude $41^{\circ} 23^{\prime} 24.7^{\prime \prime} \mathrm{N}$, longitude $2^{\circ} 9^{\prime} 14.4^{\prime \prime} \mathrm{E}$ ) is the densest Mediterranean coastal city, with about 1.6 million inhabitants in the central area and almost 5 million in the metropolitan area. According to the Köppen-Geiger climate classification (Kottek et al., 2006), the city belongs to the "Csa" region (dry Summer Mediterranean climate). The Mediterranean Sea in the southeast border and the mountain chain of "Serra de Collserola" (whose peak is 512m high) on the north-west side characterize the city's topography. To the southwest and to the north-east the metropolitan area is bounded by the valleys of the rivers Llobregat and Besos (Rodríguez Algeciras \& Matzarakis, 2016; Salvati et al., 2017) (Figure 3).

The proximity to the sea and the mountain chain is majorly impacted by urban temperature and ventilation (Stewart et al., 2014). During the entire year, the daily temperature range is relatively narrow (Table 1); prevailing wind directions are West and South-West in summer, North and North-west in winter (Salvati et al., 2017). The urban texture is continuous, dense, and compact; the average height of buildings ranges between 15 and $30 \mathrm{~m}$. According to the different ages of planning, urban blocks' size varies within the city (Salvati et al., 2017).

L'Eixample is located in the central district that composed of similar large blocks interlocking an orthogonal street network (Plan Cerda) (Ealham, 2004); medieval urban structure has kept by the ancient core, while smaller urban blocks specify the district of Gràcia which is in the north of downtown on an adequate street network.

ACE, 16 (47) CC BY-ND 3.0 ES | UPC Barcelona, España | Understanding the Performance of Vertical Gardens by Using Building Simulation and its Influences on Urban Landscape. DOI: http://dx.doi.org/10.5821/ace.16.47.10321 
Figure 3. Barcelona's urban heat island effect leads to higher temperatures in the city than in the surrounding rural areas. The difference is most marked at night during winter anticyclonic conditions

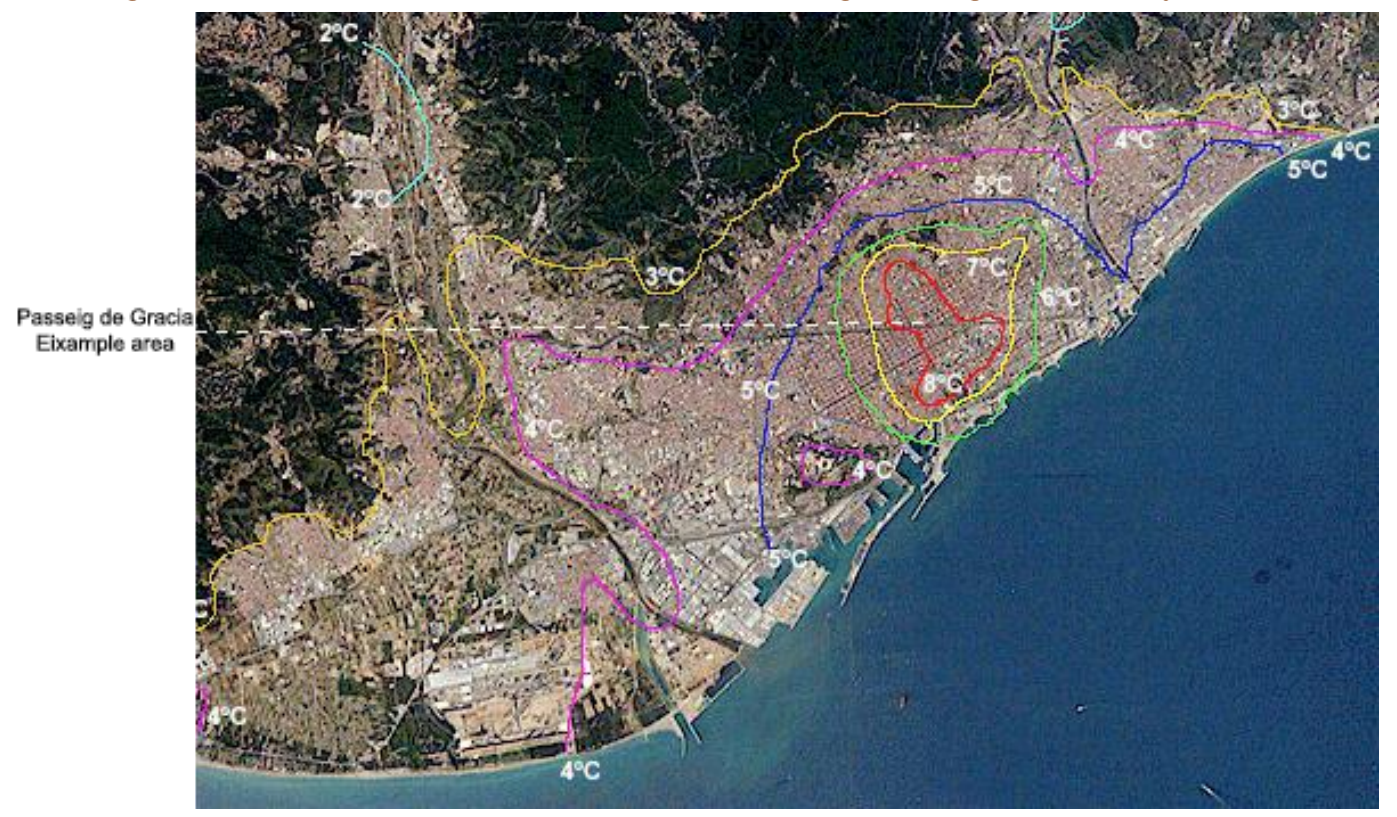

Source: Barcelona Field Studies Center (Barcelona's Urban Heat Island, n.d.).

Table 1. Barcelona weather by month/weather averages

\begin{tabular}{|c|c|c|c|c|}
\hline Month & $\begin{array}{c}\text { Temperature } \\
\left(\mathbf{C}^{\circ}\right)\end{array}$ & $\begin{array}{c}\text { Avin. } \\
\text { Temperature } \\
\left(\mathbf{C}^{\circ}\right)\end{array}$ & $\begin{array}{c}\text { Max. } \\
\text { Temperature }\left(\mathbf{C}^{\circ}\right)\end{array}$ & $\begin{array}{c}\text { Precipitation / Rainfall } \\
(\mathbf{m m})\end{array}$ \\
\hline Jan & 9.8 & 6.6 & 13.1 & 39 \\
\hline Feb & 10.7 & 7.4 & 14.1 & 36 \\
\hline Mar & 12.5 & 9 & 16.1 & 45 \\
\hline Apr & 14.6 & 10.7 & 18.6 & 48 \\
\hline May & 17.7 & 13.8 & 21.7 & 52 \\
\hline Jun & 21.4 & 17.5 & 25.3 & 42 \\
\hline Jul & 24.1 & 20.3 & 27.9 & 51 \\
\hline Aug & 23.8 & 20.2 & 27.5 & 73 \\
\hline Sep & 21.7 & 18.3 & 25.1 & 93 \\
\hline Oct & 17.6 & 14.4 & 20.9 & 59 \\
\hline Nov & 13.4 & 10.3 & 16.5 & 49 \\
\hline Dec & 10.7 & 7.7 & 13.7 & 58 \\
\hline
\end{tabular}

Note: The difference in precipitation between the driest month and the wettest month is $68 \mathrm{~mm}$. The variation in annual temperature is around $14.3^{\circ} \mathrm{C}$.

Source: https://en.climate-data.org/europe/spain/catalonia/barcelona-1564/

\subsection{Morphology and operational framework}

Generally, there are independent and dependent variables in this case. The independent variables that standalone and are not changed by the other variables in this case, for instance, climate and morphology of buildings; while, dependent variables are something that depends on other factors like a façade that could change its behavior by changing the sun's direction or wind (Nguyen et al., 2014).

ACE, 16 (47) CC BY-ND 3.0 ES | UPC Barcelona, España | Understanding the Performance of Vertical Gardens by

Using Building Simulation and its Influences on Urban Landscape. DOI: http://dx.doi.org/10.5821/ace.16.47.10321 


\subsubsection{Independent Variables}

In this research, there are four sets of independent variables: the climate profile, building morphology, building orientation, and operational framework.

- $\quad$ The climate profile: Sets of meteorological data were analyzed and the DOE-2 binary weather file used in the simulation. GBS stations are based on recent "actual year" weather data instead of CZ2 and TMY2 stations, which are based on 30-year weather data averages (Autodesk, 2011). The profile used for these simulations is the annual and monthly Barcelona weather that has been generated by this simulation software for results validation, the average temperatures calculated. (Table 2, Table 3, Figure 4).

- The building morphology: The case study is conceptional (Figure 5 - 8). The floor plan is 10 * 10 meters, which has $10 \mathrm{~m}$ high. Additionally, this case consists of exterior walls without insulation that has $300 \mathrm{~mm}$ thickness with the $10 \mathrm{~cm}$ depth cavity, made of the brick material, a glazing facade, and $40 \mathrm{~cm}$ thickness of flooring and roof and a $10 \mathrm{~cm}$ depth cavity as well. We simulated five types of green facades and bare facades (Table 4).

Table 2. The cooling and heating threshold2 in a day

\begin{tabular}{|c|c|c|c|}
\hline \multicolumn{2}{|c|}{ Cooling Degree Day } & \multicolumn{2}{c|}{ Heating Degree Day } \\
\hline Threshold & Value & Threshold & Value \\
\hline $18.3^{\circ} \mathrm{C}$ & 659 & $18.3^{\circ} \mathrm{C}$ & 1281 \\
\hline $21.1^{\circ} \mathrm{C}$ & 3.9 & $15.6^{\circ} \mathrm{C}$ & 756 \\
\hline $23.9^{\circ} \mathrm{C}$ & 83 & $12.8^{\circ} \mathrm{C}$ & 376 \\
\hline $26.7^{\circ} \mathrm{C}$ & 4 & $10^{\circ} \mathrm{C}$ & 128 \\
\hline
\end{tabular}

Source: Autodesk Green Building Studio.

Table 3. Design condition in terms of annually cooling and heating.

\begin{tabular}{|c|c|c|c|c|}
\hline \multicolumn{4}{|c|}{ Annual Design Conditions } \\
\hline \multirow{2}{*}{ Threshold } & \multicolumn{2}{|c|}{ Cooling } & Heating \\
\cline { 2 - 5 } & Dry Bulb $\left.{ }^{\circ} \mathrm{C}\right)$ & MCWB $^{4}\left({ }^{\circ} \mathrm{C}\right)$ & Dry Bulb $\left({ }^{\circ} \mathrm{C}\right)$ & MCWB $\left({ }^{\circ} \mathrm{C}\right)$ \\
\hline $0.1 \%$ & 32.1 & 22.5 & 2.0 & 1.1 \\
\hline $0.2 \%$ & 31.8 & 22.8 & 2.4 & 1.6 \\
\hline $0.4 \%$ & 31.3 & 22.4 & 2.8 & 1.5 \\
\hline $0.5 \%$ & 31.1 & 22.5 & 3.0 & 1.9 \\
\hline $1 \%$ & 30.4 & 22.6 & 3.5 & 2.5 \\
\hline $2.5 \%$ & 29.6 & 21.6 & 4.0 & 2.8 \\
\hline $5 \%$ & 29.2 & 21.3 & 4.2 & 3.8 \\
\hline
\end{tabular}

Source: Autodesk Green Building Studio.

\footnotetext{
${ }^{2}$ A threshold is a boundary that, when reached and surpassed, results in dramatically new conditions. Sometimes, thresholds are referred to as "tipping points".

${ }^{3}$ Dry Bulb is the temperature that is usually thought of as air temperature, and it is the true thermodynamic temperature.

${ }^{4}$ The MCWB is the mean coincident wet-bulb temperature.
}

ACE, 16 (47) CC BY-ND 3.0 ES | UPC Barcelona, España | Understanding the Performance of Vertical Gardens by Using Building Simulation and its Influences on Urban Landscape. DOI: http://dx.doi.org/10.5821/ace.16.47.10321 
Figure 4. Design condition in terms of temperature. Monthly Design Data (threshold of 2\%)

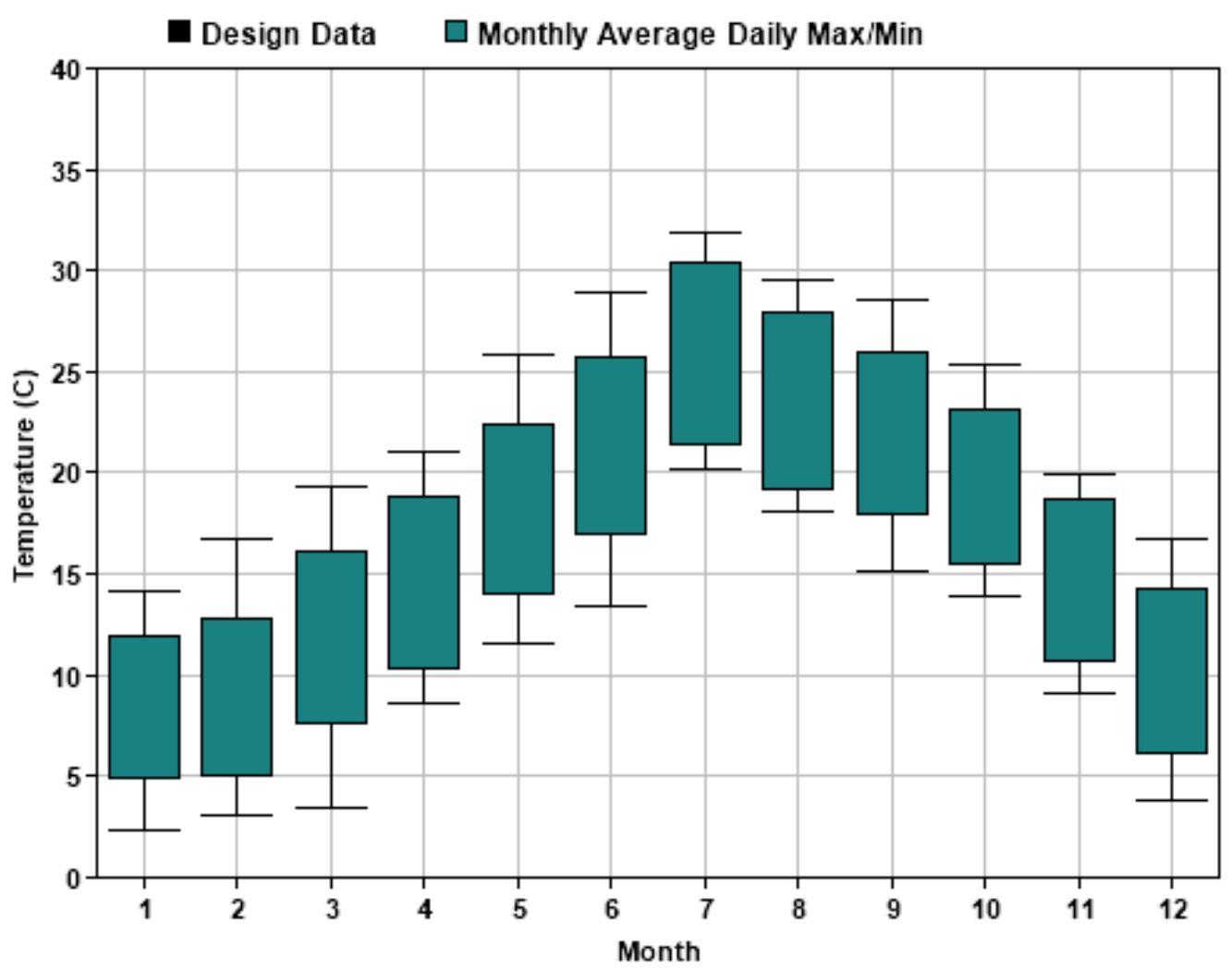

Source: Autodesk Green Building Studio.

Figure 5: The morphology of the case study $(10 * 10 * 10 \mathrm{~m})$

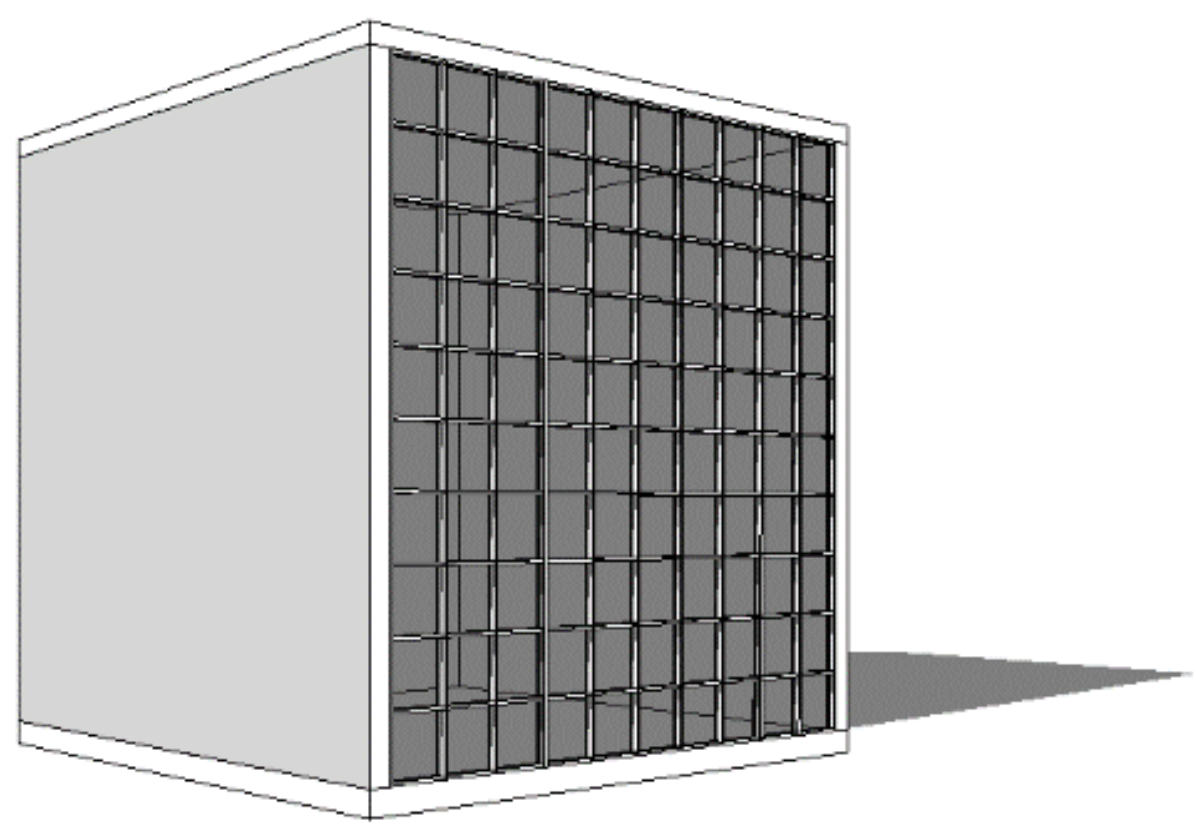

Source: By author.

ACE, 16 (47) CC BY-ND 3.0 ES | UPC Barcelona, España | Understanding the Performance of Vertical Gardens by 8 Using Building Simulation and its Influences on Urban Landscape. DOI: http://dx.doi.org/10.5821/ace.16.47.10321 
Figure 6: Details of exterior walls

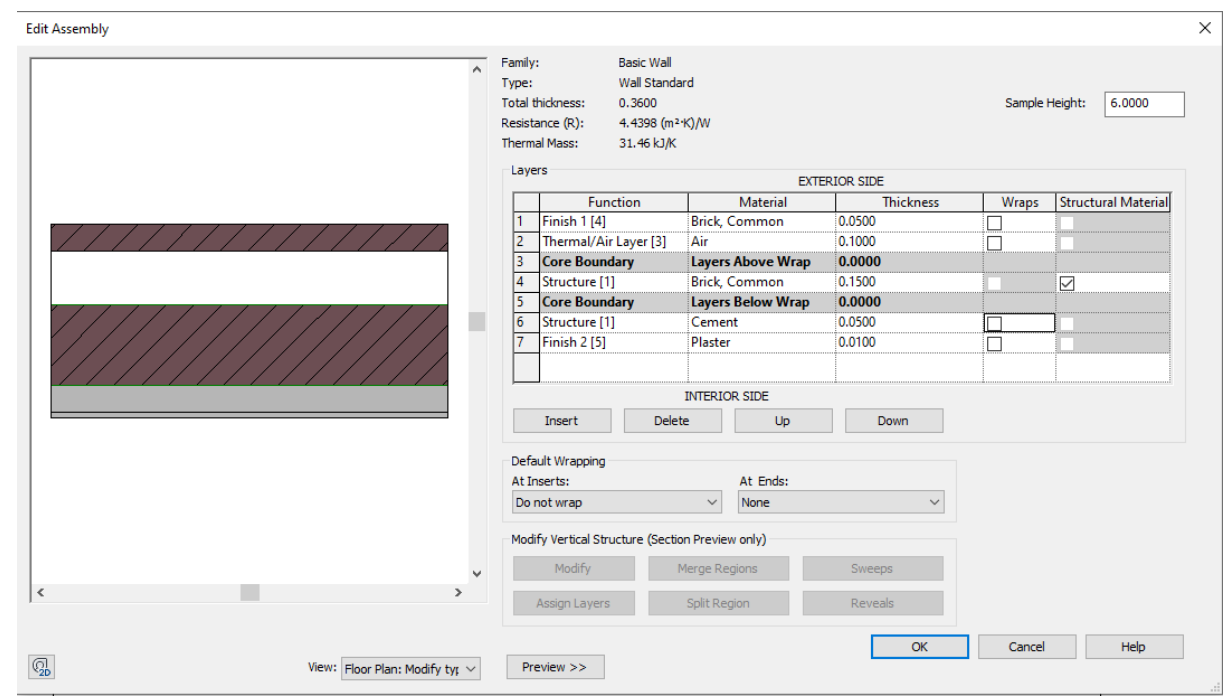

Source: By author.

Figure 7: Using the aluminum-framed wall as the structure of vertical

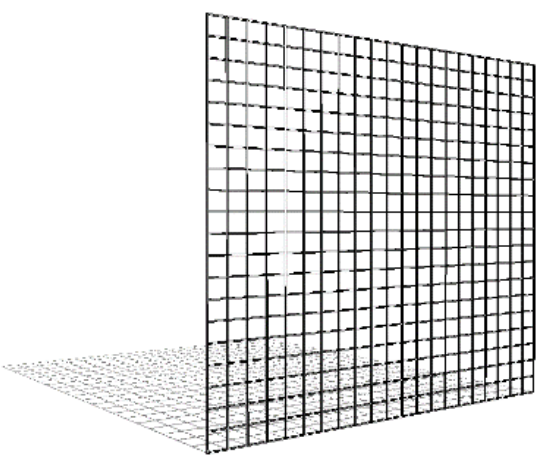

Source: By author.

Figure 8: Showing the layers of the façade

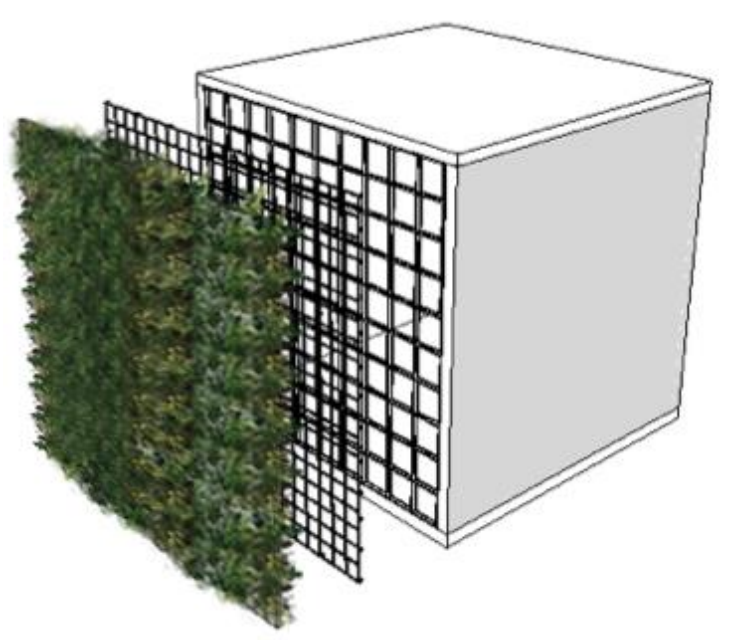

Source: By author.

ACE, 16 (47) CC BY-ND 3.0 ES | UPC Barcelona, España | Understanding the Performance of Vertical Gardens by

Using Building Simulation and its Influences on Urban Landscape. DOI: http://dx.doi.org/10.5821/ace.16.47.10321 
Table 4. The facade is placed in six styles

\begin{tabular}{|c|l|c|c|l|}
\hline Num & Facade Type & $\%$ of Greenery & Cavity & Description \\
\hline 1 & Green Skin with Cavity & $50 \%$ & $50 \mathrm{~cm}$ & $\begin{array}{l}\text { Façade-Supported Green Wall } \\
\text { (Horizontal aluminum slats) }\end{array}$ \\
\hline 2 & Green Skin with Cavity & $50 \%$ & $10 \mathrm{~cm}$ & $\begin{array}{l}\text { Façade-Supported Green Wall } \\
\text { (Horizontal aluminum slats) }\end{array}$ \\
\hline 3 & Green Skin with Cavity & $100 \%$ & $50 \mathrm{~cm}$ & $\begin{array}{l}\text { Façade-Supported Green Wall } \\
\text { (Horizontal aluminum slats) }\end{array}$ \\
\hline 5 & Green Skin with Cavity & $100 \%$ & $10 \mathrm{~cm}$ & $\begin{array}{l}\text { Façade-Supported Green Wall } \\
\text { (Horizontal aluminum slats) }\end{array}$ \\
\hline 6 & Green Skin without Cavity & $100 \%$ & 0 & $\begin{array}{l}\text { Façade Integrated Living Wall } \\
\text { (Vegetated Mat) }\end{array}$ \\
\hline
\end{tabular}

Source: By author.

- $\quad$ Building orientation: The building's orientation is vital to its overall energy efficiency (Bagheri Moghaddam et al., 2020). The case study is in the southwest (Figure 9). The building façade is facing towards the sun for about 6 hours in summer.

Figure 9. Showing the orientation of the case study

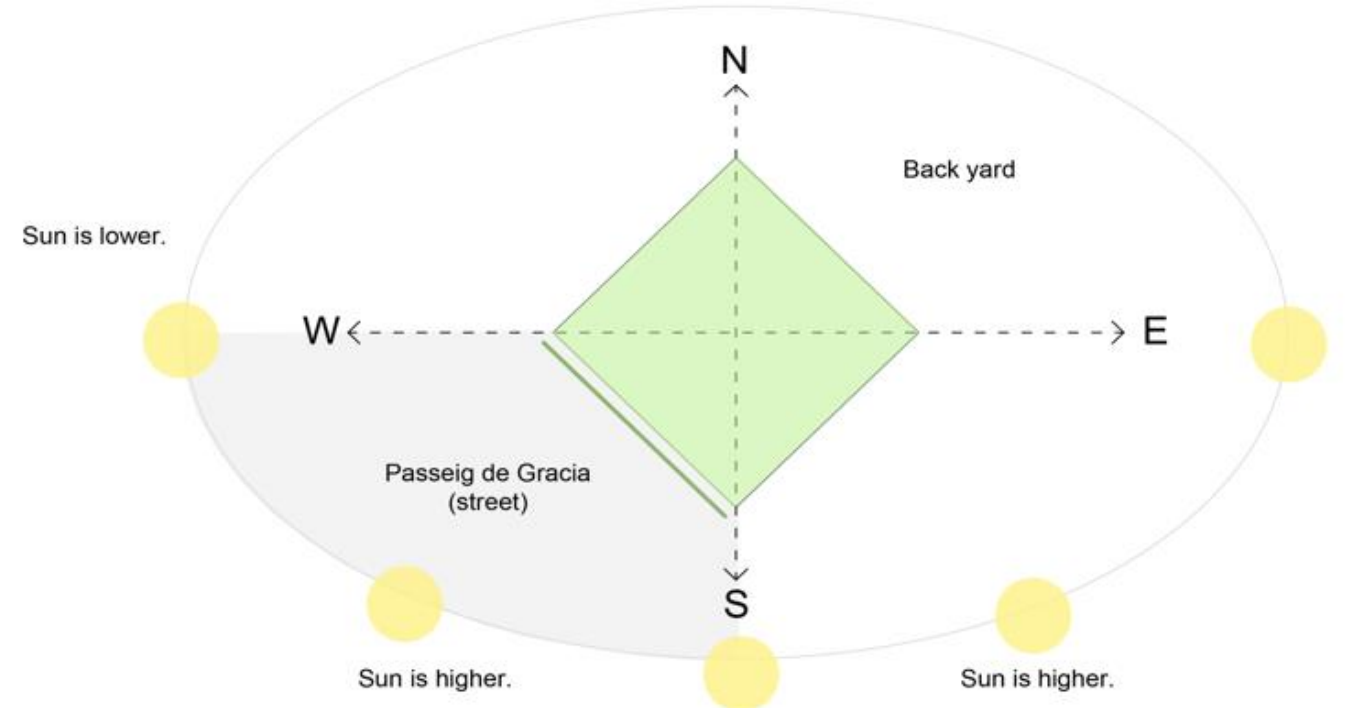

Source: By author.

- Operational framework: This part is calculated as a function of a single skin façade (glazing facade), $100 \%$ green façade without a cavity, $100 \%$ and $50 \%$ amount of surface that is covered by plants with $10 \mathrm{~cm}$ and $50 \mathrm{~cm}$ cavity. The building was operating 24 -hour M-Sat and closed on Sundays (24/6 facility).

\subsubsection{Dependent Variables}

Under the hypothesis that changing the outer skin's configuration in terms of single skin to green skin façade would substantially reduce energy consumption and change building behavior.

ACE, 16 (47) CC BY-ND 3.0 ES | UPC Barcelona, España | Understanding the Performance of Vertical Gardens by 10 Using Building Simulation and its Influences on Urban Landscape. DOI: http://dx.doi.org/10.5821/ace.16.47.10321 


\subsection{Façade scenarios}

The concept of green walls (vertical gardens) refers to all systems which enable greening a vertical surface (e.g., facades, walls, blind walls, partition walls, etc.) with a selection of plant species, including all the solutions to grow plants on, up or within the wall of a building (Building Greener, 2020; Perini et al., 2011). In this paper, the classification of green walls according to the different existing systems and their construction characteristics is proposed (Figure 10).

Figure 10. Classification of green walls, according to their construction characteristics

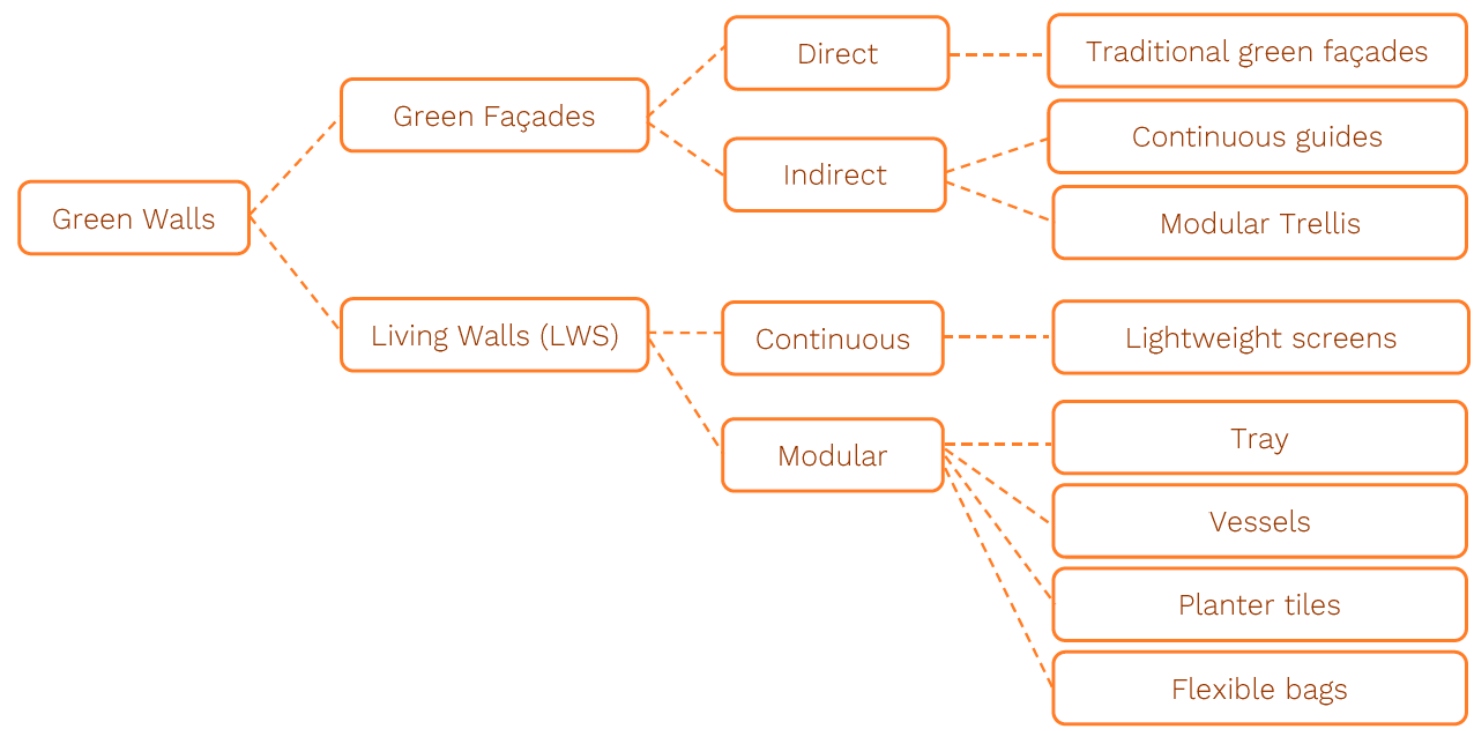

Source: M. Manso, J. Castro-Gomes / Renewable and Sustainable Energy Reviews 41 (2015) 863-871 Green

Green walls can be subdivided into two key systems: green facades and living walls (Manso \& CastroGomes, 2015; Köhler, 2008; Dunnett \& Kingsbury, 2008). The primary layer of the façade in this project has a glazing system that is an outer covering of the building in which are non-structural, used only to keep the weather out and the occupants inside. The framing is attached to the building structure and does not carry the building's floor or roof loads. Green skin without cavities is a façade-integrated living wall (which called vegetated mat). A $100 \%$ green façade with $10 \mathrm{~cm}$ and $50 \mathrm{~cm}$ cavity is considered façade-support green walls (Horizontal aluminum slats) as a type of green skin. According to the classification of green walls, is considered continuous guides indirect green façade. Finally, 50\% green skin with $10 \mathrm{~cm}$ and $50 \mathrm{~cm}$ cavity is used modular trellis indirect green façade.

\section{Result}

\subsection{The computing of total energy consumption}

The details of the implemented system inputs are the Pipe fan coil system, Chiller 5.96 Cop, and building operates M-Sat but is closed at night and Sundays (12/6 Facility). According to the simulation results, green façade can reduce energy consumption which the size of cavities depth, the amount

ACE, 16 (47) CC BY-ND 3.0 ES | UPC Barcelona, España | Understanding the Performance of Vertical Gardens by Using Building Simulation and its Influences on Urban Landscape. DOI: http://dx.doi.org/10.5821/ace.16.47.10321 
of surface that covered by plants with the high-density plants (which improving R-Value of second skin) can be very useful and significant in green facade performance (Table 5 and Table 6). By comparing the total energy consumption of all the types of facades, it can be concluded, the main façade (glazing façade) which has no other coating, because of the high use of cooling devices, are consuming energy more than other types. Due to the weather in Barcelona, there are more warm months than cold. When the green skin (100\% of the surface that is covered by plants) as a second skin is implemented directly without cavities on the main facade, it dramatically reduces energy consumption for space cooling over months. While it can obstacle getting of sunlight during the days that caused increasing heating devices then lead to raise fuel use.

The green façade can be improved by using the appropriate size of cavity depth and the amount of surface covered by the plants. For this purpose, simulated green skin using 10 and $50 \mathrm{~cm}$ of the cavity and using $100 \%$ and 50\% vegetation in the façade shows the difference in the amount of energy use (Figure 11,12). According to the result of total annual energy use intensity (Figure 11), the appropriate amount of surface covered by plants plays an important role in reducing energy use in space heating because of utilizing sun radiation by the façade, and now with dedication of proper number of plants on the façade surface, the suitable depth of cavity must be chosen which can improve the performance of green skin. Regarding Figure.11 and Figure 12, in this case, a 50\% green skin facade with a $10 \mathrm{~cm}$ cavity is more effective than a $50 \mathrm{~cm}$ cavity because of reducing energy use in ventilation fans and space cooling.

As shown in Table 5-6, with the comparison of the results of green skins simulation with the single skin façade (glazing facade), can realize that the Energy Use Intensity (EUI), total annual energy cost, total annual energy (electricity), and the total HVAC have been decreased. It should be noted that today most electrical appliances and equipment are used, especially in office buildings; therefore, reducing electricity consumption is the most critical issue.

Figure 11: Total Annual Energy Use Intensity (EUI) Bar Chart (kBtu per $\left.\mathrm{ft}^{2}\right)^{5}$

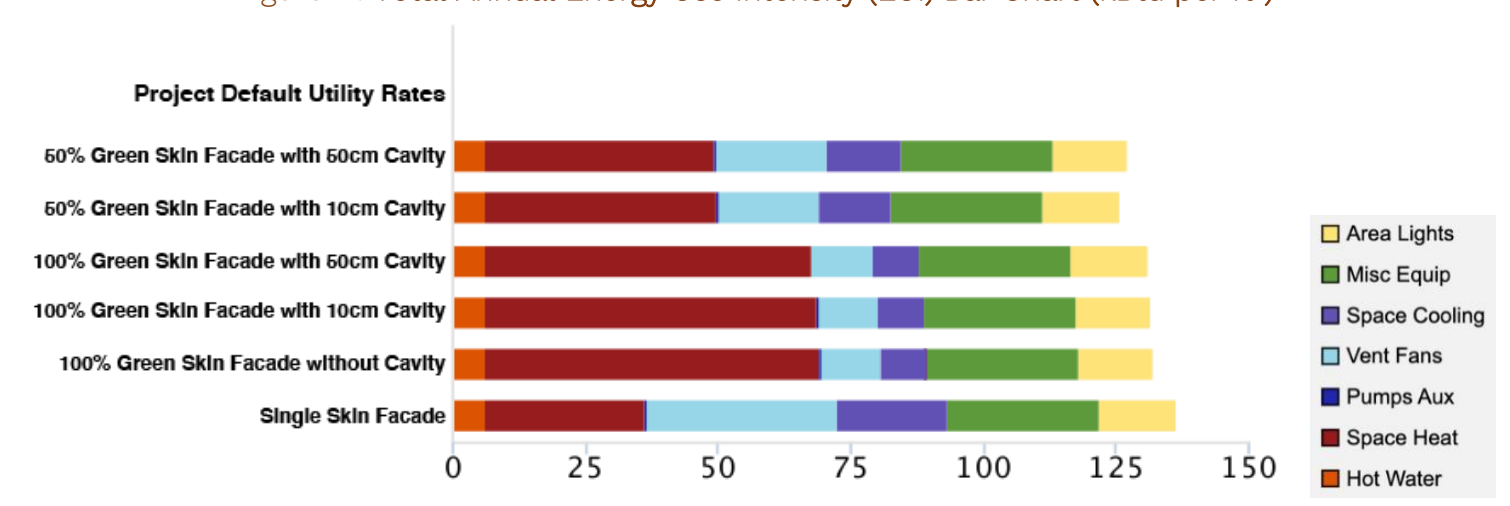

Source: By author.

\footnotetext{
${ }^{5}$ The British thermal unit (BTU or Btu) is a traditional unit of work equal to about 1055 joules. It is the amount of work needed to raise the temperature of one pound of water by one-degree Fahrenheit. The notation kBtu is used for a thousand BTU, in the sizing of heating systems and in the Energy Use Index (EUI) expressed as a thousand BTU annual energy use per square foot of the building.
}

ACE, 16 (47) CC BY-ND 3.0 ES | UPC Barcelona, España | Understanding the Performance of Vertical Gardens by Using Building Simulation and its Influences on Urban Landscape. DOI: http://dx.doi.org/10.5821/ace.16.47.10321 
Figure 12: Total Annual Energy Bar Chart (kBtu)

\section{Project Default Utility Rates}

$60 \%$ Green Skln Facade with $60 \mathrm{~cm}$ Cavlty $60 \%$ Green Skln Facade with $10 \mathrm{~cm}$ Cavity

$100 \%$ Green SkIn Facade with $60 \mathrm{~cm}$ Cavity

$100 \%$ Green Skln Facade with $10 \mathrm{~cm}$ Cavity

$100 \%$ Green SkIn Facade wlthout Cavity

SIngle Skln Facade

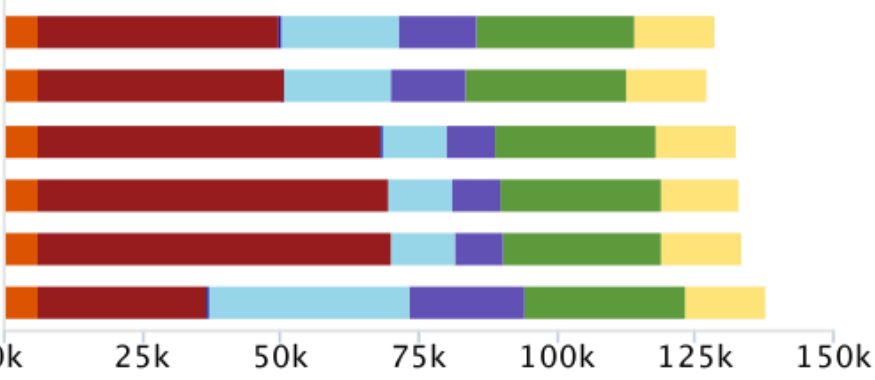

Source: By author.

Table 5. Analyze six types of façade in terms of EUI, total annual cost, and energy

\begin{tabular}{|c|c|c|c|c|c|c|c|c|c|}
\hline \multirow{2}{*}{ Facade Type } & \multirow{2}{*}{$\begin{array}{l}\text { Floor } \\
\text { Area } \\
\left(\mathrm{m}^{2}\right)\end{array}$} & \multirow{2}{*}{$\begin{array}{c}\text { EUI } \\
\left(\mathrm{MJ} / \mathrm{m}^{2} /\right. \\
\text { year })\end{array}$} & \multirow{2}{*}{$\begin{array}{c}\text { Electric } \\
\text { Cost } \\
(\mathrm{kWh})\end{array}$} & \multirow{2}{*}{$\begin{array}{l}\text { Fuel } \\
\text { Cost } \\
(\mathrm{MJ})\end{array}$} & \multicolumn{3}{|c|}{ Total Annual Cost } & \multicolumn{2}{|c|}{$\begin{array}{c}\text { Total Annual } \\
\text { Energy }\end{array}$} \\
\hline & & & & & Electric & Fuel & Energy & $\begin{array}{c}\text { Electric } \\
(\mathrm{kWh})\end{array}$ & $\begin{array}{l}\text { Fuel } \\
\text { (Mg) }\end{array}$ \\
\hline $\begin{array}{l}50 \% \text { Green Skin } \\
\text { with } 50 \mathrm{~cm} \text { Cavity }\end{array}$ & 94 & $1,443.1$ & $\in 0.13$ & $\in 0.01$ & $\in 2,888$ & $\in 609$ & $\in 3.497$ & 23,105 & 52,392 \\
\hline $\begin{array}{l}50 \% \text { Green Skin } \\
\text { with } 10 \mathrm{~cm} \text { Cavity }\end{array}$ & 94 & $1,423.8$ & $\in 0.13$ & $\in 0.01$ & $\in 2,801$ & $\in 617$ & $\in 3,418$ & 22,409 & 53,085 \\
\hline $\begin{array}{l}100 \% \text { Green Skin } \\
\text { with } 10 \mathrm{~cm} \text { Cavity }\end{array}$ & 94 & $1,483.8$ & $\in 0.13$ & $\in 0.01$ & $\in 2,346$ & $\in 835$ & $\in 3,181$ & 18,767 & 71,828 \\
\hline $\begin{array}{l}100 \% \text { Green Skin } \\
\text { with } 50 \mathrm{~cm} \text { Cavity }\end{array}$ & 94 & $1,492.4$ & $\in 0.13$ & $\in 0.01$ & $\in 2,333$ & $\in 849$ & $\in 3,181$ & 18,661 & 73,022 \\
\hline $\begin{array}{l}100 \% \text { Green Skin } \\
\text { without Cavity }\end{array}$ & 94 & $1,496.4$ & $\in 0.13$ & $\in 0.01$ & $\in 2,325$ & $\in 855$ & $\in 3,181$ & 18,602 & 73,608 \\
\hline
\end{tabular}

Source: By author.

Table 6. Energy End-Use Table of six types of façades

\begin{tabular}{|c|c|c|c|c|c|c|c|c|}
\hline \multirow{3}{*}{ Facade Type } & \multicolumn{6}{|c|}{ Annual Electric End Use } & \multicolumn{2}{|c|}{ Annual Fuel End Use } \\
\hline & \multicolumn{4}{|c|}{ HVAC } & \multirow{2}{*}{ Lights } & \multirow{2}{*}{$\begin{array}{c}\text { Other } \\
\text { Misc } \\
\text { Equip }\end{array}$} & \multirow{2}{*}{$\begin{array}{c}\text { HVAC } \\
\text { Space } \\
\text { Heating }\end{array}$} & \multirow{2}{*}{$\begin{array}{c}\text { Other } \\
\text { Hot Water }\end{array}$} \\
\hline & $\begin{array}{l}\text { Pumps } \\
\text { \& Aux }\end{array}$ & $\begin{array}{l}\text { Space } \\
\text { Cooling }\end{array}$ & Fans & $\begin{array}{l}\text { Total } \\
\text { HVAC }\end{array}$ & & & & \\
\hline $\begin{array}{l}50 \% \text { Green Skin } \\
\text { with } 50 \mathrm{~cm} \text { Cavity }\end{array}$ & $0.4 \%$ & $17.8 \%$ & $27.0 \%$ & $45.2 \%$ & $18.2 \%$ & $36.6 \%$ & $87.5 \%$ & $12.5 \%$ \\
\hline $\begin{array}{l}50 \% \text { Green Skin } \\
\text { with } 10 \mathrm{~cm} \text { Cavity }\end{array}$ & $0.4 \%$ & $17.9 \%$ & $25.2 \%$ & $43.5 \%$ & $18.7 \%$ & $37.8 \%$ & $87.7 \%$ & $12.3 \%$ \\
\hline $\begin{array}{l}\text { 100\% Green Skin } \\
\text { with } 50 \mathrm{~cm} \text { Cavity }\end{array}$ & $0.5 \%$ & $14.1 \%$ & $17.9 \%$ & $32.5 \%$ & $22.4 \%$ & $45.1 \%$ & $90.9 \%$ & $9.1 \%$ \\
\hline $\begin{array}{l}100 \% \text { Green Skin } \\
\text { with } 10 \mathrm{~cm} \text { Cavity }\end{array}$ & $0.5 \%$ & $13.7 \%$ & $18.0 \%$ & $32.1 \%$ & $22.5 \%$ & $45.4 \%$ & $91.0 \%$ & $9.0 \%$ \\
\hline $\begin{array}{l}\text { 100\% Green Skin } \\
\text { without Cavity }\end{array}$ & $0.5 \%$ & $13.4 \%$ & $18.1 \%$ & $31.9 \%$ & $22.6 \%$ & $45.5 \%$ & $91.1 \%$ & $8.9 \%$ \\
\hline $\begin{array}{l}\text { Single Skin (Main } \\
\text { Façade) }\end{array}$ & $0.3 \%$ & $21.0 \%$ & $35.9 \%$ & $57 \%$ & $14.2 \%$ & $28.6 \%$ & $83.1 \%$ & $16.9 \%$ \\
\hline
\end{tabular}

Source: By author.

ACE, 16 (47) CC BY-ND 3.0 ES | UPC Barcelona, España | Understanding the Performance of Vertical Gardens by

Using Building Simulation and its Influences on Urban Landscape. DOI: http://dx.doi.org/10.5821/ace.16.47.10321 


\subsection{Thermal performance}

Thermal is one of the significant performances of the green facades, which means that green skin as a second skin on the facade can protect the building in hot and cold conditions (this issue will be more investigated in a future article, and this paragraph is just mentioned as one advantage of the green facade). According to the calculation of conduction heat transfer rate through the walls described by the Fourier equation (Kosloff \& Kosloff, 1983; Hockney, 1965):

$$
\mathrm{q}=\mathrm{A} \frac{\mathrm{T} 2-\mathrm{T} 1}{\mathrm{R}}
$$

Where:

$A=$ area normal to the heat flow $\left(\mathrm{m}^{2}\right)$,

$R=$ unit thermal resistance, $\left(\mathrm{m}^{2} \mathrm{~K} / \mathrm{W}\right)$,

$T 1=$ Exterior surface temperature

T2= Interior surface temperature

It can be seen the fact that if thermal resistance (R-value) increases, conduction heat transfer will be reduced in the walls (Figure 13) (Al-Sanea \& Zedan, 2012). By implementing a green facade as a second skin, the R-value of the facade will be increased, thus reducing the conduction heat transfer (Q) (Figure 14) then the energy consumption will reduce. Consequently, we can control as much as possible the heat transfer in the building envelope by adding green skin.

Figure 13: A single layer wall $(X 2-X 1=R)$

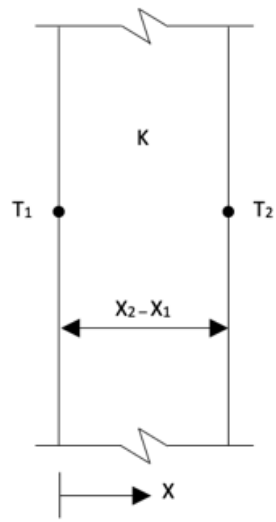

Figure 14: Energy balance of a vegetated façade

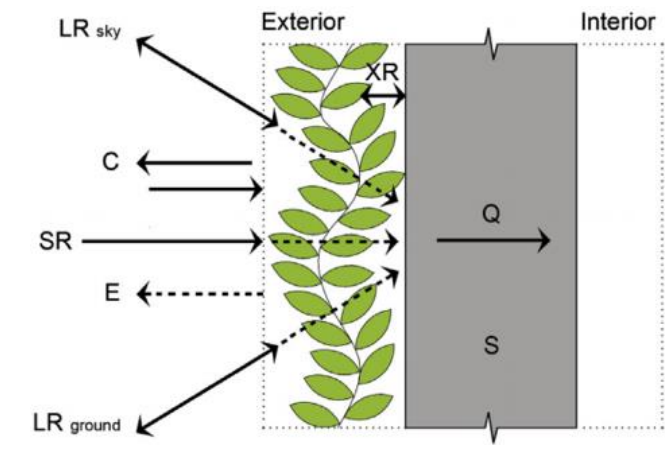

SR - shortwave radiation LR - longwave radiation

$\mathrm{XR}$ - plant-wall radiative exchange

C - convection

E - evapotranspiration

$Q$ - conduction through the facade

$\mathrm{S}$ - heat storage in the facade material

Source: Building Performance Simulation for Design and Operation Book. ISBN13: 978-0-415-47414-6 (hbk)

According to the research about the thermal performance of building facades in Illinois Institute of Technology in Chicago (Susorova et al., 2013), results show that the green skin implemented in the facade can improve thermal resistance by $0.0-0.7 \mathrm{~m}^{2} \mathrm{~K} / \mathrm{W}$; however, it also depends on wall parameters, climate zones, and plant characteristics. Several previous studies had demonstrated thermal performance in the vegetation façade. Recent studies have shown climbing plants' performance on building facades in summer that have reduced ambient air temperature about $1-3^{\circ} \mathrm{C}$ near a vegetated façade (Hoyano, 1988).

ACE, 16 (47) CC BY-ND 3.0 ES | UPC Barcelona, España | Understanding the Performance of Vertical Gardens by 14 Using Building Simulation and its Influences on Urban Landscape. DOI: http://dx.doi.org/10.5821/ace.16.47.10321 
This reduction of facade surface temperature behind of plants has varied from $8.2^{\circ} \mathrm{C}$ (Di \& Wang, 1999) to $1.9-8.3^{\circ} \mathrm{C}$ (Eumorfopoulou \& Kontoleon, 2009), which depends primarily on the density of the green skin.

\section{Discussion}

Figure 17-20 shows the performance of the green skin façade in reducing annual electric and fuel end-use, hence reducing energy consumption in the office building. Figure 15 illustrates that a single skin façade (bare façade) consumes more electric energy for HVAC and uses more fuel to heat water; on the other hand, Figure 16 demonstrates a reduction of HVAC by applying green skin like a second skin in the façade and a significant decrease in fuel consumption to heat water.

All configuration is based on applying the high density of plants in the green skin on the facade. The density of plants depends on the main facade material and building orientation. The south, southwest building because of facing over 6 hours to the sun radiation consumed more energy for cooling space and ventilation fans, in this case implementing green skin as a double skin in the facade building could be very effective to reduce the energy use of the building and also changing building behavior in terms of thermal efficiency which one of the reasons for its, adding the high amount of R-Value in the facade by applying high density of plants.

As could be expected, inner skin material is minimally influenced in this simulation. This simulation shows by strengthening the building's facade, the building behavior can be improved significantly, especially the facades that are most exposed to the intense impact of the sun or wind during the days.

Figure 15: Energy end-use charts of the single skin façade
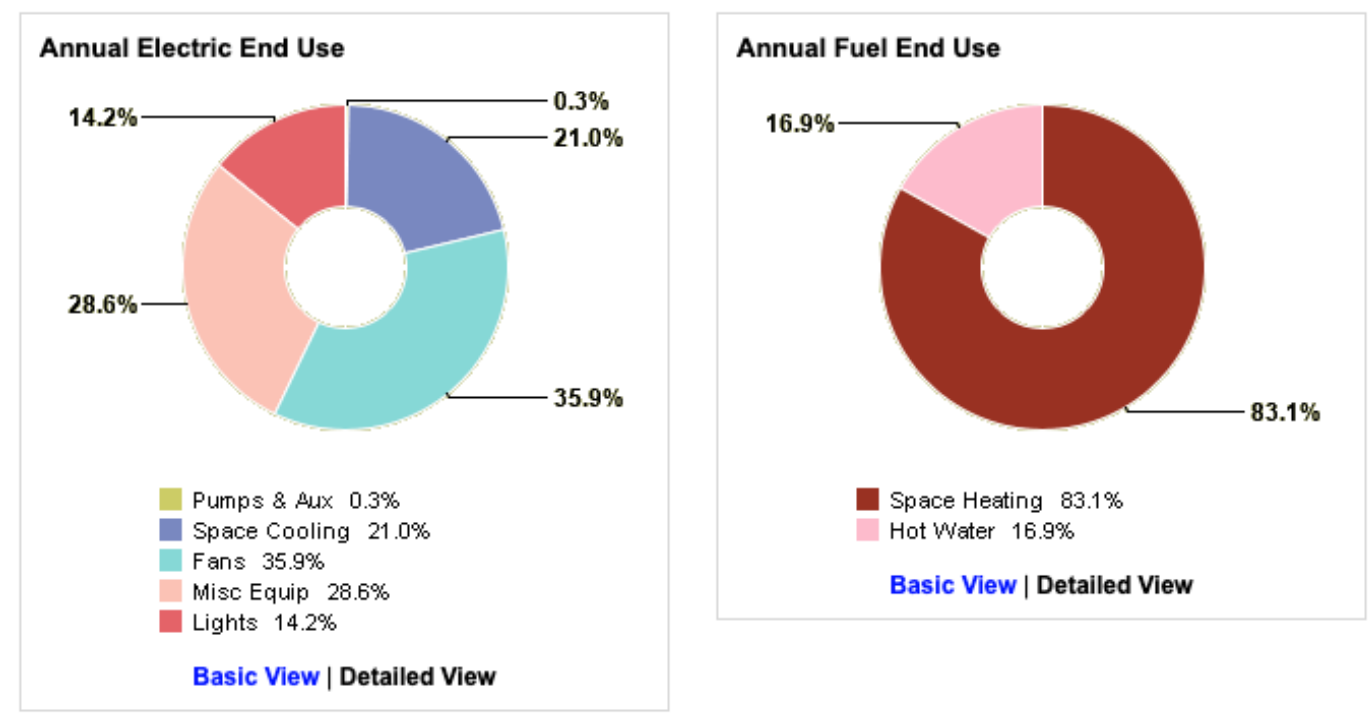

Source: By author.

ACE, 16 (47) CC BY-ND 3.0 ES | UPC Barcelona, España | Understanding the Performance of Vertical Gardens by Using Building Simulation and its Influences on Urban Landscape. DOI: http://dx.doi.org/10.5821/ace.16.47.10321 
Figure 16: Energy end-use charts of the green skin façade without the cavity
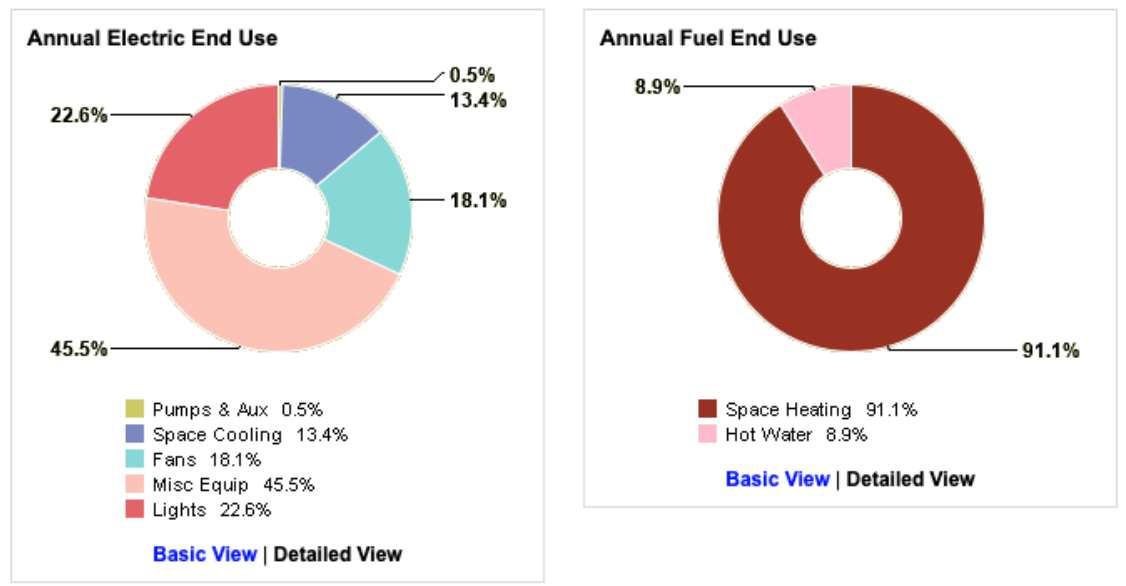

Source: By author.

Figure 17: Energy end-use charts of the $100 \%$ green skin façade with $10 \mathrm{~cm}$ cavity
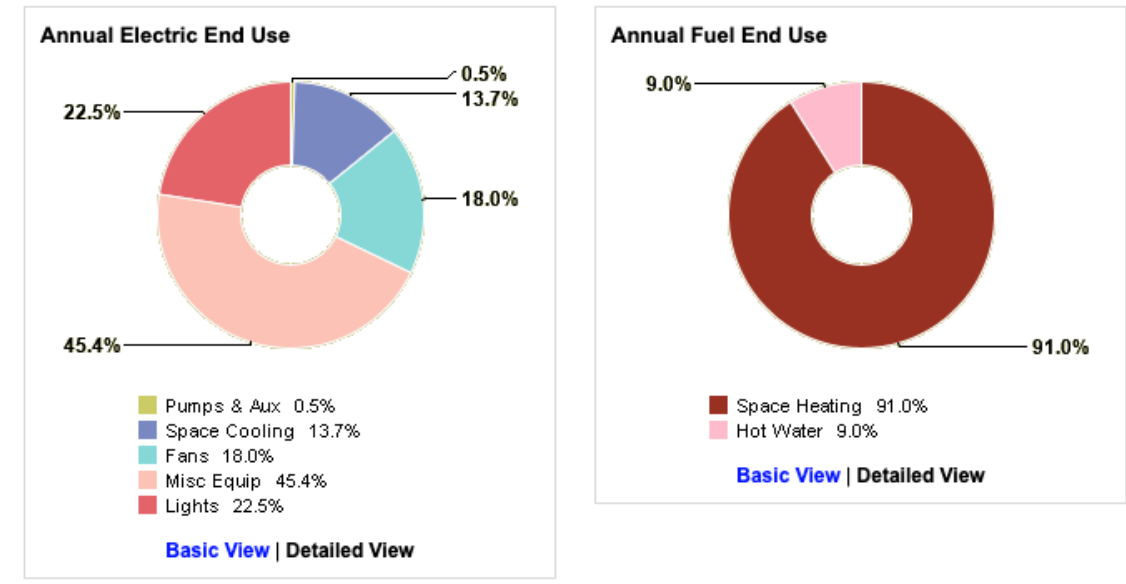

Source: By author.

Figure 18: Energy end-use charts of the $100 \%$ green skin façade with $50 \mathrm{~cm}$ cavity

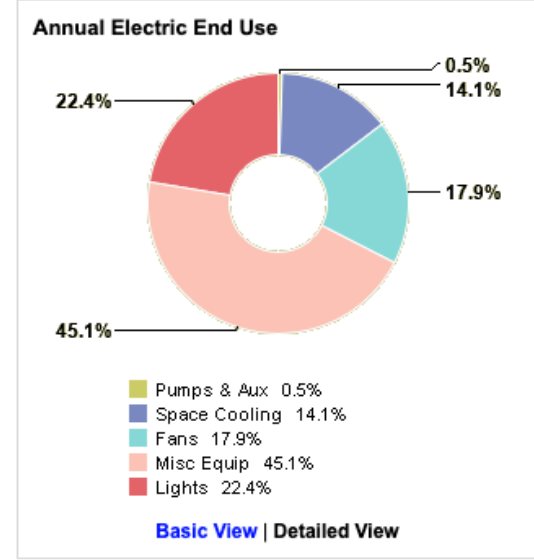

Annual Fuel End Use

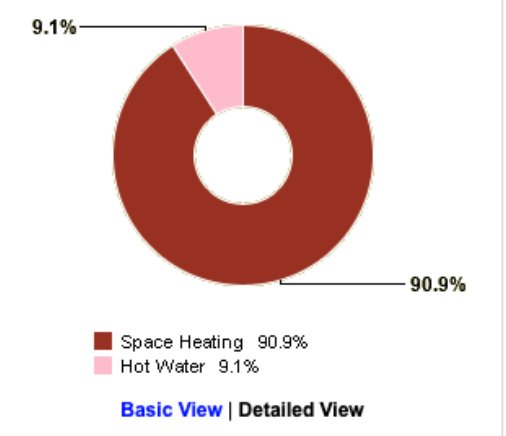

Source: By author.

ACE, 16 (47) CC BY-ND 3.0 ES | UPC Barcelona, España | Understanding the Performance of Vertical Gardens by

Using Building Simulation and its Influences on Urban Landscape. DOI: http://dx.doi.org/10.5821/ace.16.47.10321 
Figure 19: Energy end-use charts of the $50 \%$ green skin façade with $10 \mathrm{~cm}$ cavity
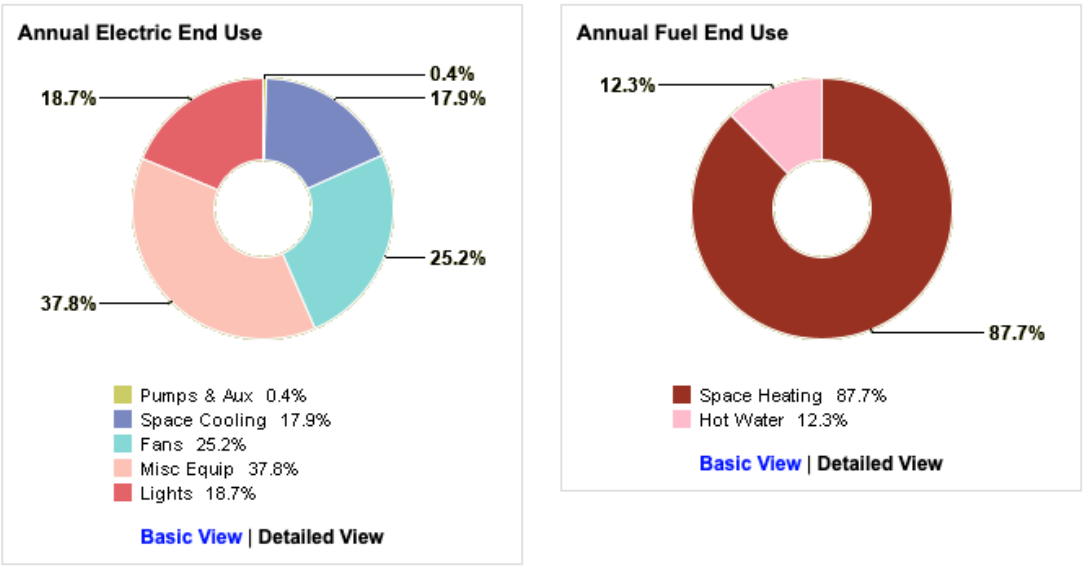

Source: By author.

Figure 20: Energy end-use charts of the $50 \%$ green skin façade with $50 \mathrm{~cm}$ cavity

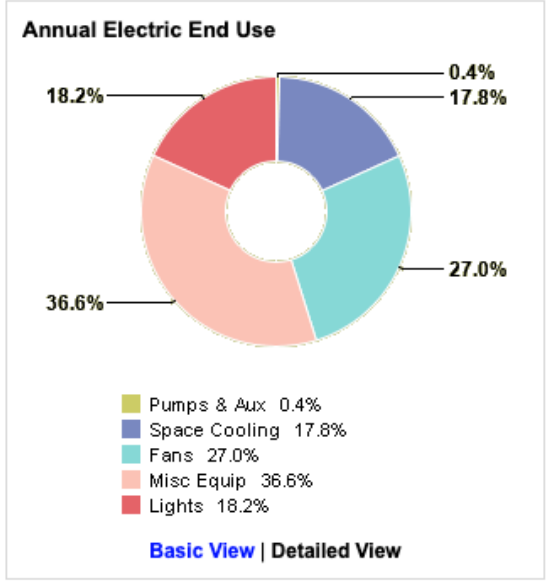

\section{Annual Fuel End Use}

$12.5 \%$

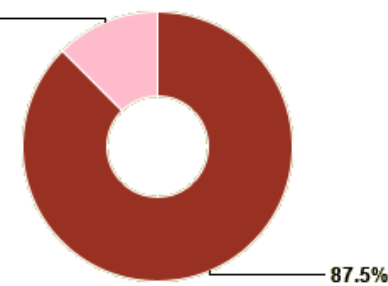

Space Heating $87.5 \%$

Hot Water $12.5 \%$

Basic View | Detailed View

Source: By author.

\section{Conclusion}

This paper discussed building simulation to understand the green façade's performance, showing the reduction of building energy demand and the changing building behavior against cold and hot weather (four seasons) in the office buildings. The paper discusses building conduct, where the best option for building façade, especially glazing facade needs to be explored. After presenting the overall structure of the green façade, the paper focuses on a case study to present the detail of how green skin can intervene in buildings' behavior helped reduce energy consumption (Table 5).

According to the building simulation result, the size of cavity depth (the space between the main facade and the green facade structure) has a crucial role in green facade performances, and how much area of the façade covered by plants that would be essential to use solar radiation and natural light, and the density of plants which enhance remarkably R-Value (thermal resistance) of the green façade. By applying the green façade with $100 \%$ covered by plants, the use of space heating will be increased because of preventing façade against sun radiation; while the use of ventilation fans and space cooling is going to decrease (Figure 17-18). Provided, in the green façade with 50\% covered by

ACE, 16 (47) CC BY-ND 3.0 ES | UPC Barcelona, España | Understanding the Performance of Vertical Gardens by 
plants, the use of space heating will be less than the green façade with $100 \%$ covered by plants, but the use of ventilation fans and space cooling becomes grow and, in this case, using $50 \%$ green façade with $10 \mathrm{~cm}$ cavity causes to reduce the ventilation fans and space cooling, compared with $50 \%$ green façade with $50 \mathrm{~cm}$ cavity (Figure 19-20).

Furthermore, in a city like Barcelona, which has warm months more than cold, space cooling and ventilating are more demanded and green façades can respond for reducing cooling space. Nonetheless, these two factors' characteristics depend on various factors such as weather, building height, and building orientation. For a better and precise cognition of the green facade performance, presented a conceptional case study in a Mediterranean climate (Köppen climate classification: Csa), with mild winters and hot summers. This approach has a southwestern orientation which is located in Passeig de Gràcia, L'Eixample area of Barcelona. This demonstrates that even for a straightforward example there is a need to explore many potential behavioral alternatives, leading to significant computational complexity. In future research, will be investigating potential behaviors of green facades as a small scale in the city's landscape which can cause to exchange the city to Biophilic city and according to Biophilic cities (Beatley, 2011) definition, nature can reduce urban heat island (HUI); therefore, energy consumption in building envelop will be decreased.

\section{Acknowledgement}

This research was supported by the National Program of Research, Development and Innovation aimed to the Society Challenges with the references BIA2016-77464-C2-1-R \& BIA2016-77464-C2-2R, both of the National Plan for Scientific Research, Development and Technological Innovation 20132016, Government of Spain, titled "Gamificación para la enseñanza del diseño urbano y la integración en ella de la participación ciudadana (ArchGAME4CITY)", and "Diseño Gamificado de visualización 3D con sistemas de realidad virtual para el estudio de la mejora de competencias motivacionales, sociales y espaciales del usuario (EduGAME4CITY)". (AEI/FEDER, UE).

\section{Author Contributions}

Conceptualization, F.B.M and I.N.D; methodology, F.B.M and I.N.D; software, F.B.M; validation, J.M.F.M, I.N.D, E.R.D and L.G.M; formal analysis, F.B.M; investigation, F.B.M; resources, F.B.M; data curation, F.B.M; writing-original draft preparation, F.B.M; writing-review and editing, F.B.M, J.M.F.M, I.N.D, and L.G.M; visualization, F.B.M; supervision, J.M.F.M and I.N.D; project administration, F.B.M; funding acquisition, E.R.D All authors have read and agreed to the published version of the manuscript.

Conflict of interests: The authors declare that there is no conflict of interest.

\section{Bibliography:}

Akbari, H., Bretz, S., Kurn, D. M., \& Hanford, J. (1997). Peak power and cooling energy savings of highalbedo roofs. Energy and Buildings, 25(2), 117-126. DOI: https://doi.org/10.1016/s0378-7788(96)01001-8

Al-Sanea, S. A., \& Zedan, M. F. (2012). Effect of thermal bridges on transmission loads and thermal resistance of building walls under dynamic conditions. Applied Energy, 98, 584-593. DOI: https://doi.org/10.1016/j.apenergy.2012.04.038

ACE, 16 (47) CC BY-ND 3.0 ES | UPC Barcelona, España | Understanding the Performance of Vertical Gardens by Using Building Simulation and its Influences on Urban Landscape. DOI: http://dx.doi.org/10.5821/ace.16.47.10321 
Aljundi, K., Pinto, A., \& Rodrigues, F. (2016). Energy Analysis Using Cooperation Between Bim Tools (Revit and Green Building Studio) and Energy Plus. 10 Congresso Português de Building Information Modelling, 1, 309-319. DOI: https://doi.org/10.5281/zenodo.166758

Autodesk. (2011). Getting Started with Autodesk Green Building Studio. Autodesk® EcotectTM Analysis 2011, 17. Retrieved from www.greenbuildingstudio.com/default.aspx.

Bagheri Moghaddam, F., Fort Mir, J. M., Besné Yanguas, A., Navarro Delgado, I., \& Redondo Dominguez, E. (2020). Building Orientation in Green Facade Performance and Its Positive Effects on Urban Landscape Case Study: An Urban Block in Barcelona. Sustainability, 12(21), 9273. DOI: https://doi.org/10.3390/su12219273

Bagheri Moghaddam, F., Fort Mir, J. M., Navarro Delgado, I., \& Redondo Dominguez, E. (2021). Evaluation of Thermal Comfort Performance of a Vertical Garden on a Glazed Façade and its Effect on Building and Urban Scale, Case Study: An Office Building in Barcelona. Sustainability, 13(12), 6706. DOI: https://doi.org/10.3390/su13126706

Barcelona's Urban Heat Island. (2020). Retrieved from https://geographyfieldwork.com/BarcelonaHeatlsland.htm\#

Beatley, T. (2011). Biophilic Cities Integrating Nature Into Urban Design and Planning. Island Press. DOI: https://doi.org/1597267147, 9781597267144

Bilgen, S. (2014). Structure and environmental impact of global energy consumption. Renewable and Sustainable Energy Reviews, 38, 890-902. DOI: https://doi.org/10.1016/j.rser.2014.07.004

Building Greener: Guidance on the Use of Green Roofs, Green Walls and Complementary Features on $\begin{array}{lllll}\text { Buildings (CIRIA } & \text { Publication). } & \text { (2020). } & \text { Retrieved }\end{array}$ http://108152724.readingmaterial.xyz/isbnfileusa.php?q=

Crawl, D. B. (2008). Estimating the impacts of climate change and urbanization on building performance. Journal of Building Performance Simulation, 1(2), 91-115. DOI: https://doi.org/10.1080/19401490802182079

D’Agostino, D., Cuniberti, B., \& Bertoldi, P. (2017). Energy consumption and efficiency technology measures in European non-residential buildings. Energy and Buildings, 153(2017), 72-86. DOI: https://doi.org/10.1016/j.enbuild.2017.07.062

D’Agostino, D., Zangheri, P., \& Castellazzi, L. (2017). Towards nearly zero energy buildings in Europe: A focus on retrofit in non-residential buildings. Energies, 10(1). DOI: https://doi.org/10.3390/en10010117

Dall'o', G., Galante, A., \& Torri, M. (2012). A methodology for the energy performance classification of residential building stock on an urban scale. Energy and Buildings, 48, 211-219. DOI: https://doi.org/10.1016/j.enbuild.2012.01.034

De La Flor, F. S., \& Domínguez, S. A. (2004). Modelling microclimate in urban environments and assessing its influence on the performance of surrounding buildings. Energy and Buildings, 36(5), 403413. DOI: https://doi.org/10.1016/j.enbuild.2004.01.050

De Wilde, P., Pahl, S., Hamza, N., Wei, S., Jones, R., \& AboHela, I. (2013). Using building simulation to drive changes in occupant behaviour: A pilot study. Proceedings of BS 2013 13th Conference of the International Building Performance Simulation Association, 3208-3215.

ACE, 16 (47) CC BY-ND 3.0 ES | UPC Barcelona, España | Understanding the Performance of Vertical Gardens by Using Building Simulation and its Influences on Urban Landscape. DOI: http://dx.doi.org/10.5821/ace.16.47.10321 
Di, H. F., \& Wang, D. (1999). Cooling effect of ivy on a wall. Experimental Heat Transfer, 12(3), 235-245. DOI: https://doi.org/10.1080/089161599269708

Djedjig, R., Bozonnet, E., \& Belarbi, R. (2015). Analysis of thermal effects of vegetated envelopes: Integration of a validated model in a building energy simulation program. Energy and Buildings, 86, 93-103. DOI: https://doi.org/10.1016/i.enbuild.2014.09.057

Double-skin facades: integrated planning - Ghent University Library. (2020). https://lib.ugent.be/en/catalog/rug01:000695707

Dunnett, N., \& Kingsbury, N. (2008). Planting green roofs and living walls. Timber.

Ealham, C. (2004). Class, culture, and conflict in Barcelona, 1898-1937. In Class, Culture and Conflict in Barcelona, 1898-1937. Routledge Taylor \& Francis Group. DOI: https://doi.org/10.4324/9780203493557

Economidou, M., Laustsen, J., Ruyssevelt, P., \& Staniaszek, D. (2011). Europe' S Buildings Under the Microscope (Issue October). Retrieved from https://bpie.eu/wpcontent/uploads/2015/10/HR EU B under microscope study.pdf

Efficiency, S. E., \& Summary, E. (2011). Energysavingand efficiencyaction plan2011·2020 2.

Eumorfopoulou, E. A., \& Kontoleon, K. J. (2009). Experimental approach to the contribution of plantcovered walls to the thermal behaviour of building envelopes. Building and Environment, 44(5), 10241038. DOI: https://doi.org/10.1016/j.buildenv.2008.07.004

European System of Accounts. (1995). Retrieved from https://ec.europa.eu/eurostat/web/productsmanuals-and-guidelines/-/ca-15-96-001

Frenger, P., Moberg, P., Malmodin, J., Jading, Y., \& Gódor, I. (2011). Reducing energy consumption in LTE with cell DTX. IEEE Vehicular Technology Conference. DOI: https://doi.org/10.1109/VETECS.2011.5956235

GhaffarianHoseini, A., GhaffarianHoseini, A., Berardi, U., Tookey, J., Li, D. H. W., \& Kariminia, S. (2016). Exploring the advantages and challenges of double-skin facacdes (DSFs). Renewable and Sustainable Energy Reviews, 60, 1052-1065. DOI: https://doi.org/10.1016/j.rser.2016.01.130

Grimmond, S. (2007). Urbanization and global environmental change: Local effects of urban warming. Geographical Journal, 173(1), 83-88. DOI: https://doi.org/10.1111/j.1475-4959.2007.232_3.x

Hans-Martin, F., Stéphane, Mikael, H., \& Stefan, F. (2012). Climate change impacts and vulnerability in Europe 2012. European Environment Agency. Retrieved from: https://www.eea.europa.eu/publications/climate-impacts-and-vulnerability-2012

Hassid, S., Santamouris, M., Papanikolaou, N., Linardi, A., Klitsikas, N., Georgakis, C., \& Assimakopoulos, D. N. (2000). Effect of the Athens heat island on air conditioning load. Energy and Buildings, 32(2), 131141. DOI: https://doi.org/10.1016/S0378-7788(99)00045-6

Hensen, J. L. M., \& Lamberts, R. (2011). Building simulation for practical operational optimization. In Building Performance Simulation for Design and Operation. Routledge. DOI: https://doi.org/10.4324/9780203891612

ACE, 16 (47) CC BY-ND 3.0 ES | UPC Barcelona, España | Understanding the Performance of Vertical Gardens by Using Building Simulation and its Influences on Urban Landscape. DOI: http://dx.doi.org/10.5821/ace.16.47.10321 
Hockney, R. W. (1965). A Fast Direct Solution of Poisson's Equation Using Fourier Analysis. Journal of the ACM (JACM), 12(1), 95-113. DOI: https://doi.org/10.1145/321250.321259

Hoyano, A. (1988). Climatological uses of plants for solar control and the effects on the thermal environment of a building. Energy and Buildings, 11(1-3), 181-199. DOI: https://doi.org/10.1016/0378$\underline{7788(88) 90035-7}$

Hwang, R. L., Lin, C. Y., \& Huang, K. T. (2017). Spatial and temporal analysis of urban heat island and global warming on residential thermal comfort and cooling energy in Taiwan. Energy and Buildings, 152, 804-812. DOI: https://doi.org/10.1016/j.enbuild.2016.11.016

Invidiata, A., \& Ghisi, E. (2016). Impact of climate change on heating and cooling energy demand in houses in Brazil. Energy and Buildings, 130(2016), 20-32. DOI: https://doi.org/10.1016/j.enbuild.2016.07.067

Köhler, M. (2008). Green facades-a view back and some visions. Urban Ecosystems, 11(4), 423-436. DOI: https://doi.org/10.1007/s11252-008-0063-x

Kolokotroni, M., Ren, X., Davies, M., \& Mavrogianni, A. (2012). London's urban heat island: Impact on current and future energy consumption in office buildings. Energy and Buildings, 47, 302-311. DOI: https://doi.org/10.1016/j.enbuild.2011.12.019

Kosloff, D., \& Kosloff, R. (1983). A Fourier Method Solution for the Time Dependent Schrddinger Equation as a Tool in Molecular Dynamics. Journal of Computational Physics, 53, 35-53. DOI: https://doi.org/10.1016/0021-9991(83)90015-3

Kottek, M., Grieser, J., Beck, C., Rudolf, B., \& Rubel, F. (2006). World map of the Köppen-Geiger climate classification updated. Meteorologische Zeitschrift, 15(3), 259-263. DOI: https://doi.org/10.1127/09412948/2006/0130

Li, X., Zhou, Y., Yu, S., Jia, G., Li, H., \& Li, W. (2019). Urban heat island impacts on building energy consumption: A review of approaches and findings. Energy, 174, 407-419. DOI: https://doi.org/10.1016/j.energy.2019.02.183

Lund, H., \& Mathiesen, B. V. (2009). Energy system analysis of 100\% renewable energy systems-The case of Denmark in years 2030 and 2050. Energy, 34(5), 524-531. DOI: https://doi.org/10.1016/j.energy.2008.04.003

Luziani, S., \& Paramita, B. (2019). Autodesk Green Building Studio an Energy Simulation Analysis in the Design Process. KnE Social Sciences, 2019, 735-749. DOI: https://doi.org/10.18502/kss.v3i21.5007

Manso, M., \& Castro-Gomes, J. (2015). Green wall systems: A review of their characteristics. Renewable and Sustainable Energy Reviews, 41(January), 863-871. DOI: https://doi.org/10.1016/j.rser.2014.07.203

Nguyen, A. T., Reiter, S., \& Rigo, P. (2014). A review on simulation-based optimization methods applied to building performance analysis. Applied Energy, 113, 1043-1058. DOI: https://doi.org/10.1016/j.apenergy.2013.08.061

Øren, P. E., Bakke, S., \& Arntzen, O. J. (1998). Extending Predictive Capabilities to Network Models. SPE Journal, 3(4), 324-335. DOI: https://doi.org/10.2118/52052-pa

ACE, 16 (47) CC BY-ND 3.0 ES | UPC Barcelona, España | Understanding the Performance of Vertical Gardens by Using Building Simulation and its Influences on Urban Landscape. DOI: http://dx.doi.org/10.5821/ace.16.47.10321 
Oxizidis, S., Dudek, A. V., \& Papadopoulos, A. M. (2008). A computational method to assess the impact of urban climate on buildings using modeled climatic data. Energy and Buildings, 40(3), 215-223. DOI: https://doi.org/10.1016/j.enbuild.2007.02.018

Palme, M., Inostroza, L., Villacreses, G., Lobato-Cordero, A., \& Carrasco, C. (2017). From urban climate to energy consumption. Enhancing building performance simulation by including the urban heat island effect. Energy and Buildings, 145, 107-120. DOI: https://doi.org/10.1016/j.enbuild.2017.03.069

Pérez-Lombard, L., Ortiz, J., \& Pout, C. (2008). A review on buildings energy consumption information. Energy and Buildings, 40(3), 394-398. DOI: https://doi.org/10.1016/j.enbuild.2007.03.007

Perini, K., Ottelé, M., Haas, E. M., \& Raiteri, R. (2011). Greening the building envelope, facade greening and living wall systems. Open Journal of Ecology, 01(01), 1-8. DOI: https://doi.org/10.4236/oje.2011.11001

Plan Bleu(Regional Activity Center). (2015). Climate Change and Energy in the Mediterranean. Retrieved from https://www.eib.org/attachments/country/climate_change_energy_mediterranean_en.pdf

Poirazis, H. (2004). Double Skin Façades for Office Buildings Division of Energy and Building Design. Retrieved from https://www.scirp.org/(S(lz5map453edsnp55rrgjct55))/reference/ReferencesPapers.aspx?Referencel $\mathrm{D}=2524424$

Rakhshandehroo, M., Mohd Yusof, M. J., \& Deghati Najd, M. (2015). Green Façade (Vertical Greening): Benefits and Threats. Applied Mechanics and Materials, 747(March), 12-15. DOI: https://doi.org/10.4028/www.scientific.net/amm.747.12

Rey, F. J., Velasco, E., \& Varela, F. (2007). Building Energy Analysis (BEA): A methodology to assess building energy labelling. Energy and Buildings, 39(6), 709-716. DOI: https://doi.org/10.1016/j.enbuild.2006.07.009

Rodríguez Algeciras, J. A., \& Matzarakis, A. (2016). Quantification of thermal bioclimate for the management of urban design in Mediterranean climate of Barcelona, Spain. International Journal of Biometeorology, 60(8), 1261-1270. DOI: https://doi.org/10.1007/s00484-015-1121-8

Rosenfeld, A. H., Akbari, H., Bretz, S., Fishman, B. L., Kurn, D. M., Sailor, D., \& Taha, H. (1995). Mitigation of urban heat islands: materials, utility programs, updates. Energy and Buildings, 22(3), 255-265. DOI: https://doi.org/10.1016/0378-7788(95)00927-P

Rosenfeld, A. H., Akbari, H., Romm, J. J., \& Pomerantz, M. (1997). Cool Communities: srategies for heat island mitigation and smog reduction (pp. 51-62). DOI: https://doi.org/10.1016/S0378-7788(97)00063-7

Salvati, A., Coch Roura, H., \& Cecere, C. (2017). Assessing the urban heat island and its energy impact on residential buildings in Mediterranean climate: Barcelona case study. Energy and Buildings, 146, 38-54. DOI: https://doi.org/10.1016/j.enbuild.2017.04.025

Skjærseth, J. B., \& Wettestad, J. (2010). Fixing the EU emissions trading system? understanding the post-2012 changes. Global Environmental Politics, 10(4), 101-123. DOI: https://doi.org/10.1162/GLEP a 00033

Stewart, I. D., Oke, T. R., \& Krayenhoff, E. S. (2014). Evaluation of the "local climate zone" scheme using temperature observations and model simulations. International Journal of Climatology, 34(4), 10621080. DOI: $\underline{\text { https://doi.org/10.1002/joc.3746 }}$

ACE, 16 (47) CC BY-ND 3.0 ES | UPC Barcelona, España | Understanding the Performance of Vertical Gardens by Using Building Simulation and its Influences on Urban Landscape. DOI: http://dx.doi.org/10.5821/ace.16.47.10321 
Sun, Y., \& Augenbroe, G. (2014). Urban heat island effect on energy application studies of office buildings. Energy and Buildings, 77, 171-179. DOI: https://doi.org/10.1016/j.enbuild.2014.03.055

Susorova, I., Angulo, M., Bahrami, P., \& Brent Stephens. (2013). A model of vegetated exterior facades for evaluation of wall thermal performance. Building and Environment, 67, 1-13. DOI: https://doi.org/10.1016/j.buildenv.2013.04.027

Toleikyte, A., Kranzl, L., Bointner, R., Bean, F., Cipriano, J., Groote, M. De, Hermelink, A., Klinski, M., Kretschmer, D., Lapilonne, B., Pascual, R., Rajkiewicz, A., Santos, J., Schimschar, S., Sebi, C., \& Volt, J. (2016). ZEBRA 2020 Nearly zero - energy building strategy 2020: Strategies for a nearly Zero-Energy Building market transition in the European Union. Retrieved from www.zebra2020.eu

Verbong, G., \& Loorbach, D. (2012). Governing the energy transition: Reality, illusion, or necessity? Routledge. DOI: https://doi.org/10.4324/9780203126523

Yezioro, A., Dong, B., \& Leite, F. (2008). An applied artificial intelligence approach towards assessing building performance simulation tools. Energy and Buildings, 40(4), 612-620. DOI: https://doi.org/10.1016/j.enbuild.2007.04.014

Zhao, H. X., \& Magoulès, F. (2012). A review on the prediction of building energy consumption. In Renewable and Sustainable Energy Reviews 16(6), 3586-3592. DOI: https://doi.org/10.1016/j.rser.2012.02.049

ACE, 16 (47) CC BY-ND 3.0 ES | UPC Barcelona, España | Understanding the Performance of Vertical Gardens by 